Article

\title{
A Modular Cell Balancer Based on Multi-Winding Transformer and Switched-Capacitor Circuits for a Series-Connected Battery String in Electric Vehicles
}

\author{
Thuc Minh Bui ${ }^{1}{ }^{(1)}$, Chang-Hwan Kim ${ }^{1}{ }^{[D}$, Kyu-Ho Kim ${ }^{2}$ and Sang Bong Rhee ${ }^{1, *}$ \\ 1 Department of Electrical Engineering, Yeungnam University, Gyeongsan, Gyeongbuk 38541, Korea; \\ minhbt@ntu.edu.vn (T.M.B.); kranz@ynu.ac.kr (C.-H.K.) \\ 2 Department of Electrical Engineering, Hankyong National University, Anseong, Kyonggi 17579, Korea; \\ kyuho@hknu.ac.kr \\ * Correspondence: rrsd@yu.ac.kr; Tel.: +82-53-810-3097
}

Received: 30 June 2018; Accepted: 30 July 2018; Published: 1 August 2018

\begin{abstract}
In this paper, a cell balancing topology for a series-connected Lithium-Ion battery string (SCBS) in electric vehicles is proposed and experimentally verified. In particular, this balancing topology based on the modular balancer consists of an intra-module balancer based on a multi-winding transformer circuit and an outer-module balancer based on a switched capacitor converter, both offering the potential advantages and over conventional balancing methods, including short equalization time, simple control scheme, elimination of voltage sensors. In addition, a number of cells in the SCBS can be easily extended in this circuit. Furthermore, a system structure and an operating principle of the proposed topology are analyzed and experimentally verified for three different cases. The voltages of all cells in the SCBS reached the balanced state regardless of the various arrangement of the initial voltage, where the energy efficiency of the circuit reached $83.31 \%$. Our experimental realization of the proposed balancing topology shows that such a technique could be employed in electric vehicles.
\end{abstract}

Keywords: series-connected battery string; electric vehicles; modular cell balancing; multi-winding transformer; switched capacitor converter

\section{Introduction}

For the past decades, the series-connected battery string (SCBS) has been widely used in several applications of energy storage systems for electric vehicles (EVs), hybrid electric vehicles (HEVs), subway and electric railroad [1-6] that require high voltage and capacity. The balance of the SCBS plays an important role in chemical and electrical characteristics of a battery string. In fact, the battery lifetime and the energy storage capacity are decreased due to an unbalance of the SCBS generated through the repeated charge and discharge operation. Particularly, this imbalance can lead to fire and/or explosion in the worst case [7]. Thus, the series-connected battery string in EVs needs to be balanced with the voltage [8]. In practice, internal and external sources are known as two main reasons that cause the unbalance of the battery cells $[8,9]$. For internal sources, the deviation in production results in variations of storage capacity value, total internal impedance, and rated self-discharge. In the case of the external sources, multi-rank rack protection Integrated circuits (ICs) primarily lead the unequal charge from the various series ranks in the pack [8].

Recently, the cell balancing methods have been introduced [10-20] and reviewed [7,8,21-23], as represented in Figure 1. There are two main ways to equalize a battery cell, which are passive and active methods $[8,22]$. Resistors are used in the passive cell balancing methods, which are connected 
in parallel with the battery cells to avoid overcharging through passive components so that one can equalize the low cells. Due to the power consumption of resistors, this method has low efficiency as reported in the literature [8]. The active cell balancing methods are based on inductors, capacitors and switched controllers or converters, the energy of the cells is transmitted from a high to a low voltage level $[8,11,14]$. Therefore, the active balancing method has higher efficiency than the passive balancing method as reported in the literature $[7,8]$.

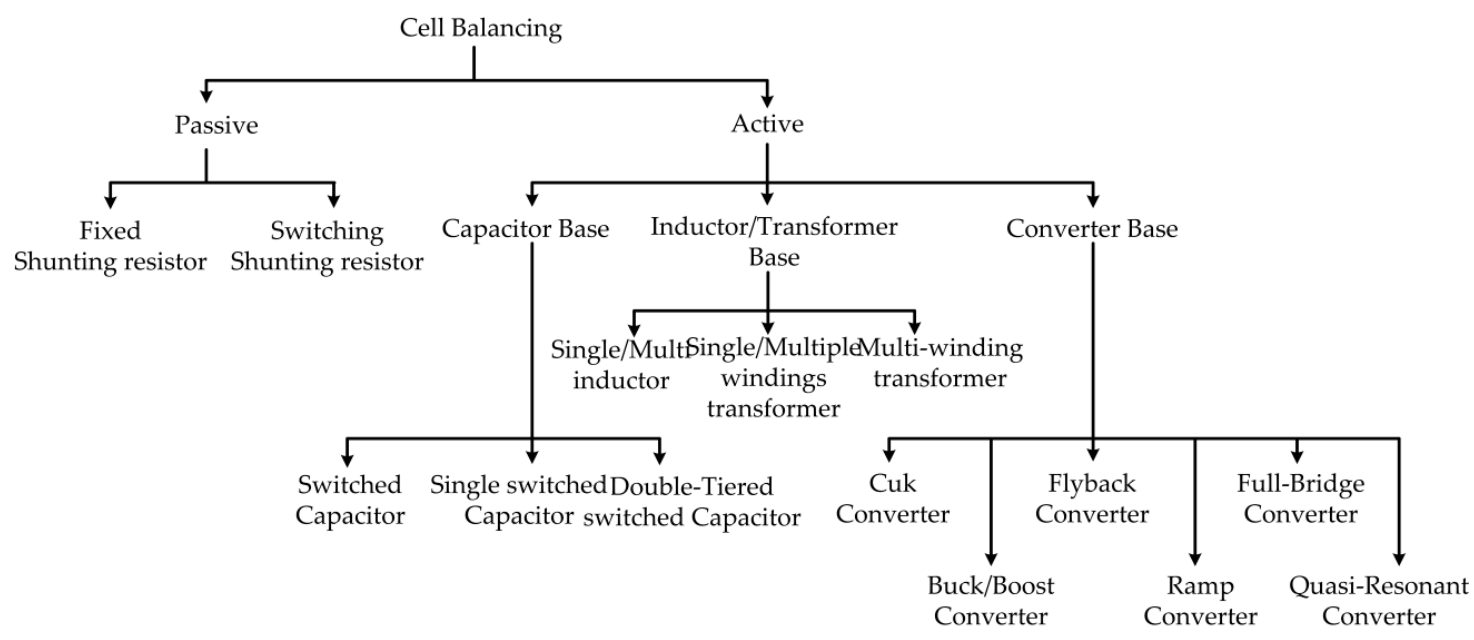

Figure 1. The classifications of conventional battery cell balancer [21].

The balancing method based on a multi-winding transformer (MWT) [18-20,24,25] has advantages such as fast balancing speed, simple control technique, and repudiation of voltage sensors. Nevertheless, this circuit has the complexity of fabricating MWT, a limited number of windings due to the parameter matching for the turns ratio, and leakage inductance, especially for a large number of cells. The MWT-based balancing circuit was improved by applying forward-flyback conversion [23] to balance the cells. The buck-boost converter-based cell balancing, which reduces switching loss to obtain high efficiency, is applied to EVs and HEVs $[12,23,26]$. However, this balancing technique requires an intelligent control and a large number of switches, resulting in relative complexity and high cost. In addition, a balancing method based on a switched capacitor circuit (SCC) $[11,15,26,27]$ has been widely utilized in energy storage applications thanks to advantages such as simple design and control and elimination of a voltage sensor for each cell. Importantly, the SCC can be employed in the modular method as well. However, the balancing time is long, especially for a large SCBS since the energy is transferred between adjacent battery cells (i.e., cell to cell balancer). It is known that a higher number of cells and/or larger voltage difference between cells result in longer balancing time.

There is a limited number of studies on battery balancing topology such as the requirements of voltage sensors, intelligent control, more importantly, the limited number of cells in the SCBS. Therefore, a novel modular cell balancing circuit (MCBC) is proposed to solve these limitations. In this approach, the SCBS, divided into several modules, is a balanced proposed MCBC, which consists of an intra-module and outer-module balancers. The intra-module balancer based on the MWT circuit with the forward converter structure (MWTFC) circuit is used to transfer energy between the cells inside each module, whereas the SCC based on the outer-module balancer is applied to transfer the energy between the modules simultaneously. This balancing technique effectively deals with a small number of cells when designing a balancing circuit. Therefore, the design of this balancing circuit becomes much easier. Furthermore, the proposed circuit has numerous advantages of two conventional circuits and overcomes disadvantages that these conventional circuits were unable to eliminate. The structure and operational principles of the proposed $\mathrm{MCBC}$ are described in detail. The experimental results are presented to verify the efficacy of the proposed balancing topology. 


\section{Proposed Modular Cell Balancing Circuit}

\subsection{Analysis of the Previous Cell Balancing Circuits}

\subsubsection{Active Cell Balancing Circuit Using the MWT}

Figure 2 shows an active cell balancing circuit using the MWT with the forward converter structure and operating modes $[17,18,21,25,28]$. This circuit consists of $N$ series-connected cells. Each cell in the SCBS is associated with a primary winding of the MWT $(T)$ and a power switch $S_{k}(k=1, \ldots, 4)$. A diode (D) on the secondary side is used to reset the magnetizing inductance of the transformer. The MWTFC-based balancer equalizes the voltage of cells in the SCBS by selectively turning the switches $S_{k}$ on or off according to the constant duty cycle $(D)$ simultaneously.

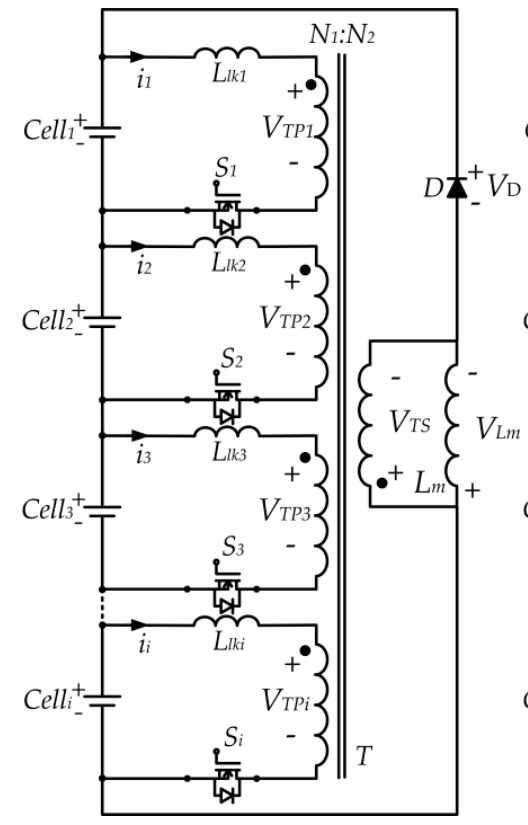

(a)

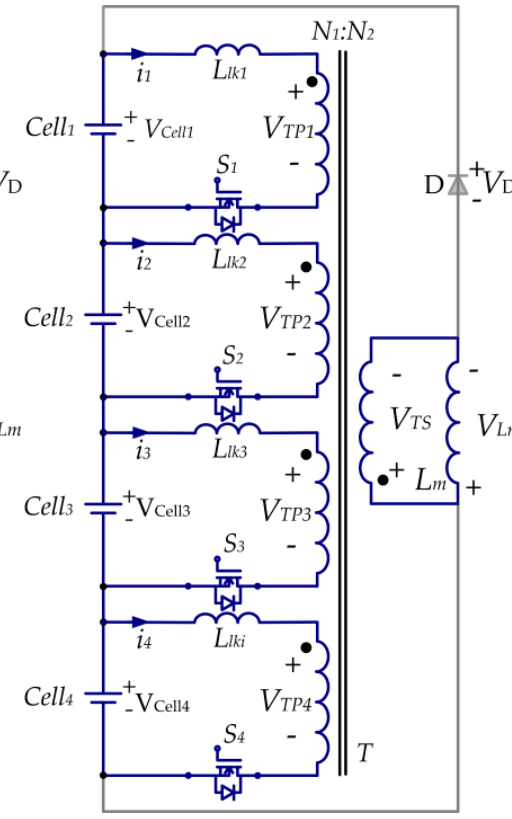

(b)

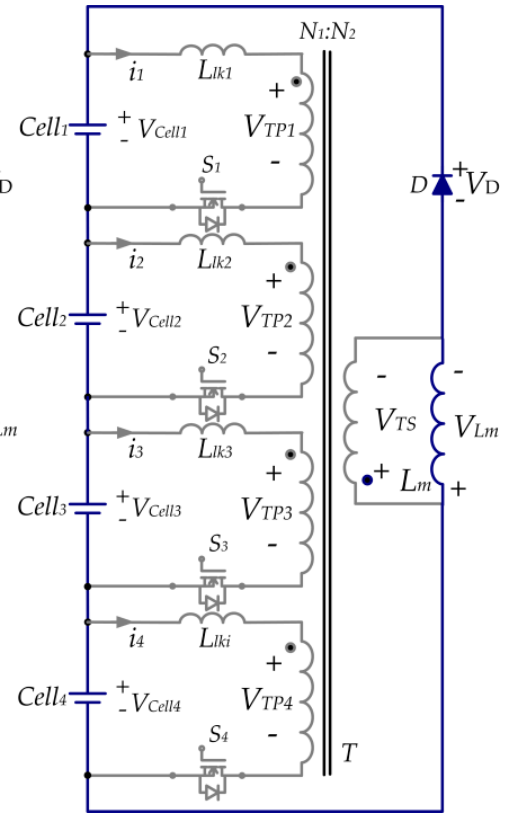

(c)

Figure 2. The MWTFC based on the balancing circuit [21]: (a) Circuit diagram; (b) Mode 1; (c) Mode 2.

Three operational modes in one switching period $\left(T_{\mathrm{s}}\right)$ of the circuit and the operation waveforms are shown in Figures $2 b, c$ and 3, respectively. In order to simply analyze the operating modes for the circuit, it is assumed that this circuit includes four series-connected cells; The relationship among the voltage of the battery cells is assumed as follows: $V_{\text {cell1 }}>V_{\text {cell2 }}>V_{\text {aver }}>V_{\text {cell3 }}>V_{\text {cell4 }}$, the sum voltage is $V_{\text {Total }}=V_{\text {cell1 }}+V_{\text {cell2 }}+V_{\text {cell3 }}+V_{\text {cell4 }}$, and the average voltage is $V_{\text {aver }}$ where $V_{\text {cell1 }}, V_{\text {cell2, }}$, $V_{\text {cell3 }}$, and $V_{\text {cell4 }}$ represent the voltage across $\mathrm{Cell}_{1}, \mathrm{Cell}_{2}, \mathrm{Cell}_{3}$, and Cell 4 , respectively. The operating modes of the circuit are presented as follows:

Mode $1\left[t_{0}, t_{1}\right]$ (see Figure $2 \mathrm{~b}$ ): At $t_{0}$, four switches $\left(S_{1}, S_{2}, S_{3}\right.$, and $\left.S_{4}\right)$ are turned on simultaneously as shown in Figure 3. In this mode, the energy is transferred from high voltage level cells (i.e., Cell, $\mathrm{Cell}_{2}$ ) to the low one (i.e., $\mathrm{Cell}_{3}, \mathrm{Cell}_{4}$ ) through the transformer $\mathrm{T}$.

In mode 1, there are four loops forming four equations, and each loop equation can be expressed as Equation (1). Figure 4 shows an equivalent circuit. The relationship among the current of a magnetizing inductance $L_{\mathrm{m}}, i_{\mathrm{Lm}}$, and cell currents $i_{1}, i_{2}, i_{3}$ and $i_{4}$, and voltage across $L_{\mathrm{m}}, V_{\mathrm{Lm}}$, can be expressed as Equations (2) and (3):

$$
\begin{gathered}
V_{T P i}=V_{\text {aver }}=V_{\text {Celli }}-L_{l k i} \frac{d i_{i}}{d t} \\
i_{L m}=i_{1}+i_{2}+i_{3}+i_{4},
\end{gathered}
$$




$$
V_{L m}=L_{m} \frac{d i_{L m}}{d t}
$$

where $i_{1}, i_{2}, i_{3}$ and $i_{4}$ are the currents of four switches of $S_{1}, S_{2}, S_{3}$ and $S_{4}$, respectively.

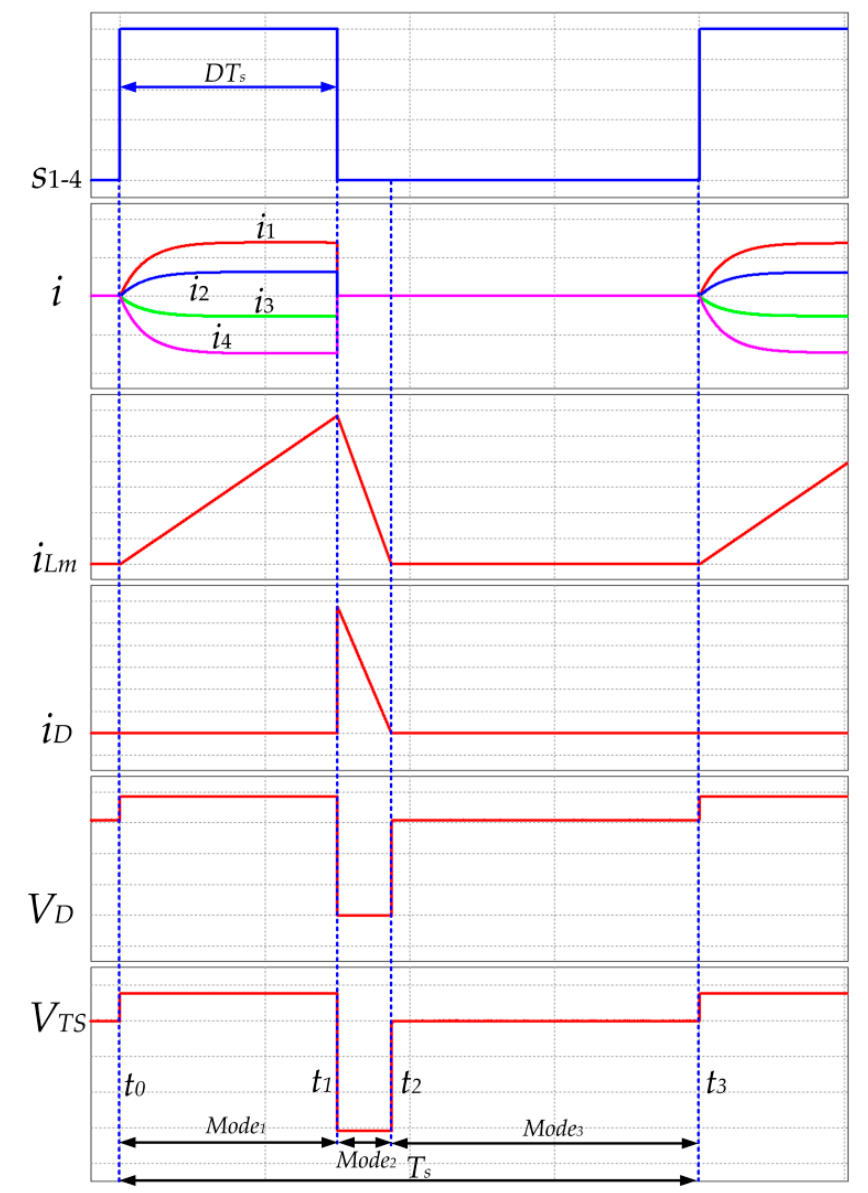

Figure 3. Operation waveforms of the cell balancing circuit.

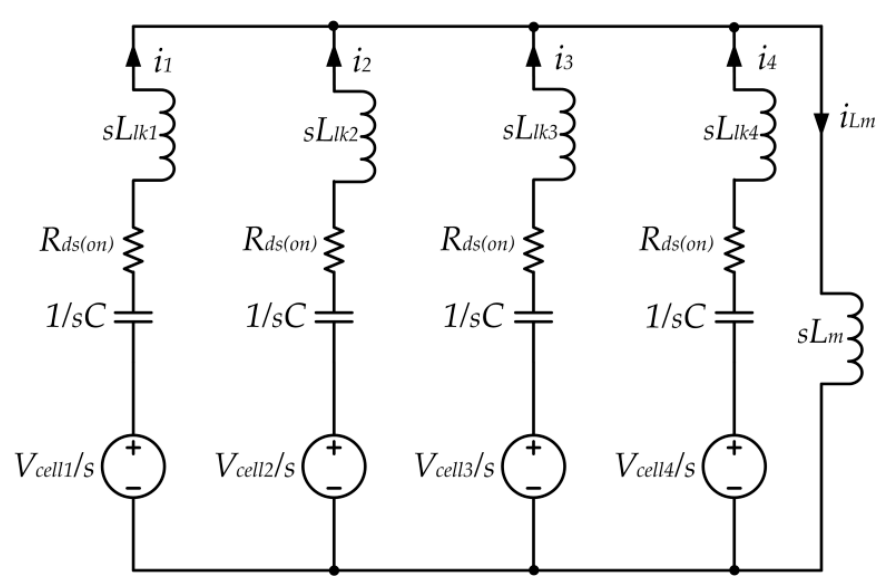

Figure 4. Laplace transform circuit of mode 1.

In this mode, four switches are turned on. The value of the leakage inductance and the magnetizing inductance can be used to apply the average voltage. From Equation (1) to Equation (3), the $V_{T P}$ can be expressed as follows: 


$$
\begin{aligned}
V_{T P}=L_{m} \frac{d i_{m}}{d t} & =L_{m} \frac{d}{d t}\left(i_{1}+i_{2}+i_{3}+i_{4}\right), \\
\frac{d}{d t} i_{1} & =\frac{V_{\text {Cell } 1}-V_{L m}}{L_{l k 1}} \\
\frac{d}{d t} i_{2} & =\frac{V_{\text {Cell } 2}-V_{L m}}{L_{l k 2}} \\
\frac{d}{d t} i_{3} & =\frac{V_{\text {Cell } 3}-V_{L m}}{L_{l k 3}} \\
\frac{d}{d t} i_{4} & =\frac{V_{\text {Cell } 4}-V_{L m}}{L_{l k 4}}
\end{aligned}
$$

In this mode, the inrush currents likely to flow in Figure 4 need to be considered. In the case, if there is a high voltage difference among the cells, the inrush currents likely to flow are large. Therefore, NTC thermistor [29] in series with the primary is suggested to limit the current. The NTC thermistor offers high resistance at the beginning of switching and limits the inrush current. After a short time, the NTC thermistor resistance decreases to a low value due to self-heating and it does not affect normal operation. However, in this study, the different voltages among the cells are small. Therefore, the circuit does not need to limit current and protect circuits. $V_{\text {Cell1 }}$ and $V_{\text {Cell2 }}$ are higher than $V_{\text {aver, }}, V_{\text {Cell3 }}$, and $V_{\text {Cell4 }}$. Therefore, currents $i_{1}, i_{2}$ flow from the cells (i.e., $C e l l_{1}$ and $\mathrm{Cell}_{2}$ ) to the transformer $T$, and $i_{3}$ and $i_{4}$ flow from $T$ to the battery cells (i.e., $\mathrm{Cell}_{3}$ and $\mathrm{Cell}_{4}$ ). This means that the electric charges in $\mathrm{Cell}_{1}, \mathrm{Cell}_{2}$ are transferred to $\mathrm{Cell}_{3}, \mathrm{Cell}_{4}$ through $\mathrm{T}$.

Mode $2\left[t_{1}, t_{2}\right]$ (see Figure 2c): At $t_{1}$, four switches are turned off simultaneously, as shown in Figure 3 . The voltage across the $L_{\mathrm{m}}$ becomes negative, $V_{\mathrm{Lm}}$. Therefore, the magnetizing inductance is reset through the diode, resulting in a decrease in the $i_{\mathrm{Lm}}$ to zero level.

$$
V_{L m}=-\left(V_{\text {Cell1 }}+V_{\text {Cell } 2}+V_{\text {Cell3 }}+V_{\text {Cell4 }}\right)
$$

Mode $3\left[t_{2}, t_{3}\right]$ : Mode 3 starts when the $i_{\mathrm{Lm}}$ is equal to zero. No current flows in the MWT from $t_{2}$ to $t_{3}$. At $t_{3}$, this mode is completed and changes to mode 1 occur in the next switching period.

This circuit has several advantages [17] such as short equalization time, simple control scheme, repudiation of the voltage sensor. However, if the SCBS is extended, the MWT requires a large number of windings. Meanwhile, this MWT is difficult to manufacture due to the parameter matching for the turns ratio and the leakage inductances. Equations (5)-(8) show that larger leakage inductances result in a smaller cell current. In other words, the balancing time is longer. In particular, the leakage inductances of the transformer are not uniform. Therefore, this causes a charge imbalance problem by itself. In order to reduce this problem, the number of windings of the transformer needs to be reduced [28]. This requirement motivates our proposed cell balancing circuit to solve these issues.

\subsubsection{Cell Balancing Circuit Using SCC}

A cell balancing circuit based on an SCC and operation modes of the circuit are shown in Figure $5[8,15,16,21]$. In order to simplify the analysis for circuit operation mode, it is assumed that the circuit has two cells and $V_{\text {Cell } 1}>V_{\text {Cell2 } 2}$. When two of four switches $\left(S_{\mathrm{a} 1}\right.$ and $S_{\mathrm{a} 2}$ or $S_{\mathrm{b} 1}$ and $\left.S_{\mathrm{b} 2}\right)$ in the balancing circuit are turned on or off, the energy is transferred from a cell to another cell via a balancing capacitor $\left(C_{b}\right)$. The switches are controlled by pulse-width-modulated (PWM) signals with fixed duty cycle $\left(50 \% T_{\mathrm{s}}\right)$, as shown in Figure 6 . The analysis of the circuit is based on a proposition of voltage of $\mathrm{Cell}_{1}$ and $\mathrm{Cell}_{2}$, as follows:

Mode $1\left[t_{0}, t_{1}\right]$ (See Figure 5b): At $t_{0}, S_{\mathrm{a} 1}$ and $S_{\mathrm{a} 2}$ are turned on, while $S_{\mathrm{b} 1}$ and $S_{\mathrm{b} 2}$ are turned off simultaneously. In this mode, the switches $S_{\mathrm{a} 1}$ and $S_{\mathrm{a} 2}$ conduct. Thus, $\mathrm{Cell}_{1}$ is connected in parallel with $C_{b}$, as shown in Figure $5 \mathrm{~b}$. $C_{b}$ starts to be charged by $C e l l_{1}$. The voltage across $C_{b}\left(v_{C b}\right)$ starts increasing, and current flows of $C_{b}\left(i_{C b}\right)$ starts decreasing, as shown in Figure 6. The instantaneous 
voltage and current of the balancing capacitor in this mode can be expressed [30] by Equations (10) and (11)

$$
\begin{gathered}
v_{C b}(t)=\left(v_{C e l l 1}-v_{C b \min }\right) \cdot\left(1-e^{\frac{-t}{R_{C h} \cdot c_{b}}}\right)+v_{C b \min } \\
i_{C b}(t)=\frac{v_{C e l l 1}-v_{C b \min }}{R_{C h}} e^{\frac{-t}{R_{C h} \cdot C_{b}}}
\end{gathered}
$$

where $R_{C h}$ is the sum of the equivalent series resistance of balancing capacitor $R_{\mathrm{ESR}}$, the turn-on resistance of two switches $S_{\mathrm{a} 1}, S_{\mathrm{a} 2}$.

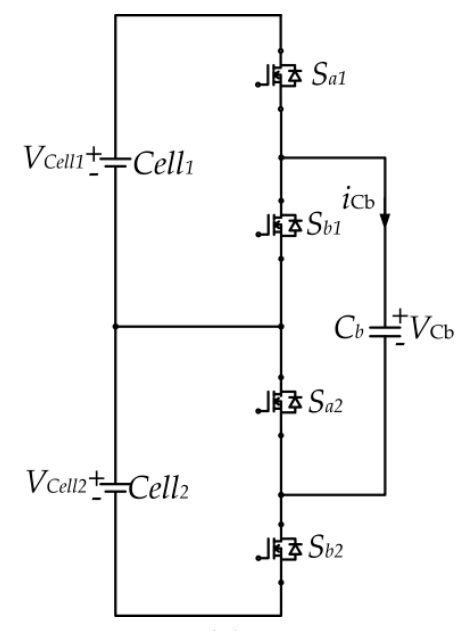

(a)

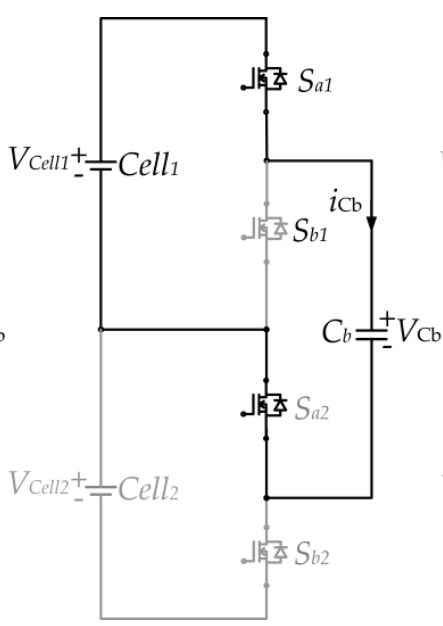

(b)

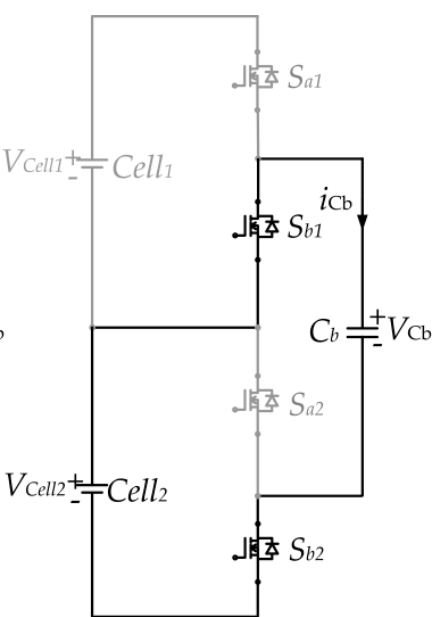

(c)

Figure 5. The switched capacitor circuit for two cells [21]: (a) Circuit description; (b) Mode 1; (c) Mode 2.

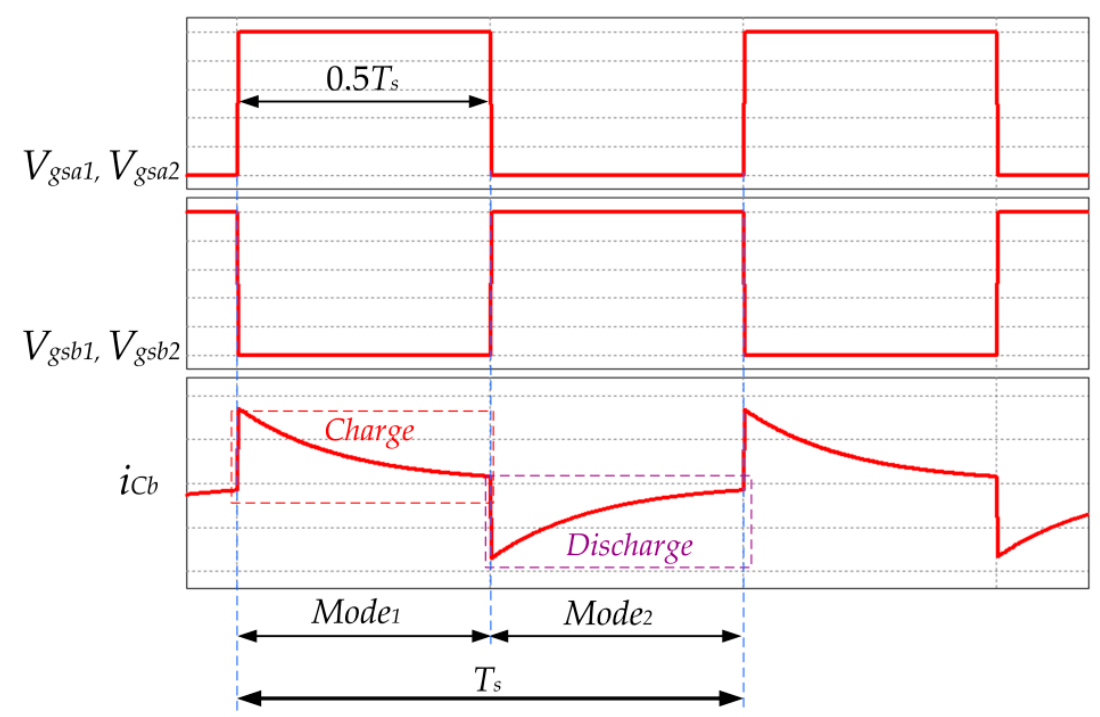

Figure 6. Operational waveforms of the switched-capacitor circuit.

Mode $2\left[t_{1}, t_{2}\right]$ (See Figure 5c): At $t_{1}, S_{\mathrm{a} 1}$ and $S_{\mathrm{a} 2}$ are turned off, and $S_{\mathrm{b} 1}$ and $S_{\mathrm{b} 2}$ are turned on simultaneously. In this mode, the switches $S_{\mathrm{b} 1}$ and $S_{\mathrm{b} 2}$ conduct. Thus, $\mathrm{Cell}_{2}$ is connected in parallel with $C_{b}$, as shown in Figure 5c. The energy of $C_{b}$ starts to be discharged to $\mathrm{Cell}_{2}$. The current of $C_{b}$ begins to boost in the opposite direction as represented in Figure 6. The instantaneous voltage across and the current of $C_{b}$ in this mode are respectively expressed in Equations (12) and (13). 


$$
\begin{gathered}
v_{C b}(t)=v_{C b \min }-\left(v_{C b \max }-v_{C e l l 2}\right) \cdot\left(1-e^{\frac{-t}{R_{d i s} \cdot C_{b}}}\right) \\
i_{C b}(t)=-\frac{v_{C b m a x}-v_{C e l l 2}}{R_{d i s}} e^{\frac{-t}{R_{d i s} \cdot C_{b}}}
\end{gathered}
$$

where $R_{\text {dis }}$ is the total of the equivalent series resistance of balancing capacitor $R_{\mathrm{ESR}}$, and the turn-on resistance of two switches $S_{\mathrm{b} 1}$ and $S_{\mathrm{b} 2}$

This circuit has some advantages [8]; for example, it does not require voltage sensors or closed-loop control. Therefore, this circuit is simple to implement with low loss. However, in the case of a large number of cells and/or the high unbalance of voltage between the cells, the equalization time is long [21]. Therefore, the novel MCBC needs to be considered carefully to reduce the mentioned disadvantages as shown in Section 2.2.

\subsection{Proposed Modular Cell Balancing Circuit}

\subsubsection{Modular Cell Balancing Concept}

Figure 7 illustrates an SCBS structure based on a conventional and modular balancing circuit [2,31-33]. The conventional cell balancer used the series-connected battery cell string, which consists of $N \times M$ cells. Therein, each cell has a separate energy transmitting path as shown in Figure 7a, whereas the modular cell balance is divided into $M$ groups of the SCBS; each module has $N$ cells, as represented in Figure $7 b, c[1,34,35]$. For the modular cell balancer, $M$ groups of the SCBS are connected with $M$ modules to balance the voltages in each module. The featured energy of cells is transferred from a high voltage level to a low level inside each module (i.e., intra-module balancer) individually. These modules can be connected to an external module balancer (i.e., outer-module balancer) to transmit the energy from a high to a low voltage level module until achieving the equalization of both energies between the modules. The modular cell balancing method is advanced for a small number of cells in comparison with the conventional method. Therefore, it is easier and more flexible than the conventional circuit in designing cell balancing for the large SCBS.

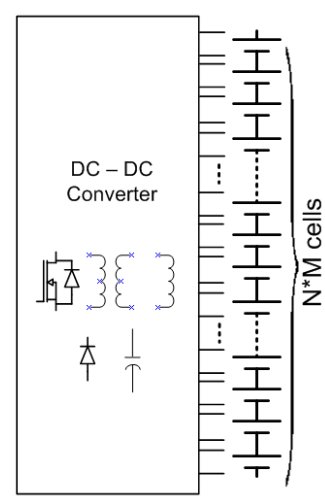

(a)

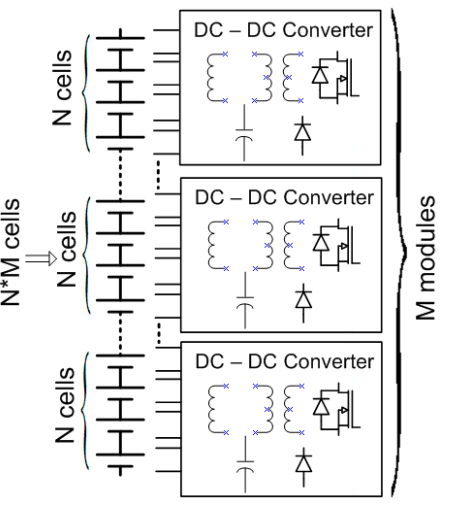

(b)

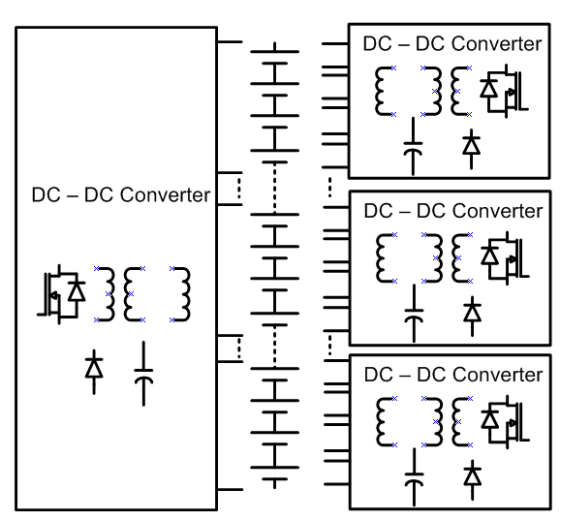

(c)

Figure 7. Modular circuit balancing concept: (a) Conventional cell balancer; (b) Modular cell balancer; (c) The modular cell balancer based on outer-module.

\subsubsection{Proposed Modular Cell Balancing Circuit}

1. System structure for proposed $\mathrm{MCBC}$

The system structure of the proposed MCBC is shown in Figure 8. This circuit is constructed by dividing the SCBS into two modules $\left(M_{1}, M_{2}\right)$ and each module contains $N$ cells in series-connection in which each cell in the SCBS connects the switch $S_{\mathrm{k}}$ and the primary side winding of the MWTs in intra-module balancers. Each MWT has a secondary side winding in connection with one diode 
to reset the magnetizing inductance of transformers $\left(L_{\mathrm{m}}\right)$ to prevent saturation of the MWTs. Each module connects with the intra-module balance individually, and all modules are connected to the outer-module balancer. In the intra-module balancer, a number of the transformer's primary windings are equal to a number of the cells inside each module. The magnetizing energy of the MWT is to balance the cell voltages in each module, and a charge/discharge process of a module balancing capacitor $\left(C_{\mathrm{m}}\right)$ is to balance the module voltages.

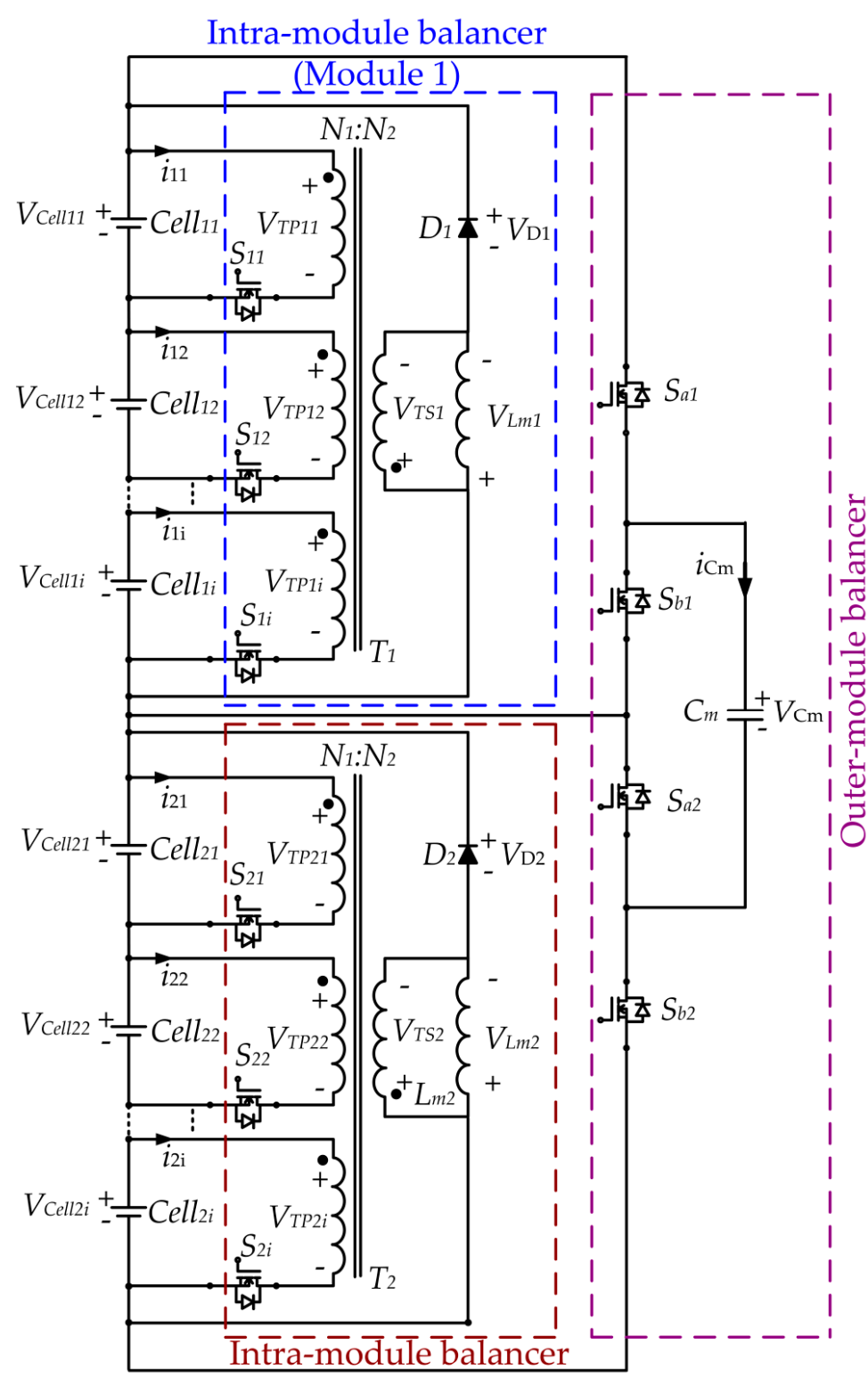

(Module 2)

Figure 8. The proposed modular cell balancing circuit.

In this proposed circuit, the energy is transferred from a high voltage level to a low voltage level in both the cells inside each module and modules simultaneously by the MWTs and the modular balancing capacitor, respectively. The $C_{\mathrm{m}}$ is used to equalize the energy between the modules through the outer-module balancer. It is controlled by the switches $S_{\mathrm{a} 1}, S_{\mathrm{a} 2}$ and $S_{\mathrm{b} 1}, S_{\mathrm{b} 2}$ which are controlled by PWM signals, as shown in Figure 9. Voltage sensors and intelligent control circuit are not used in this MCBC. Therefore, the circuit has been simply designed and controlled. 


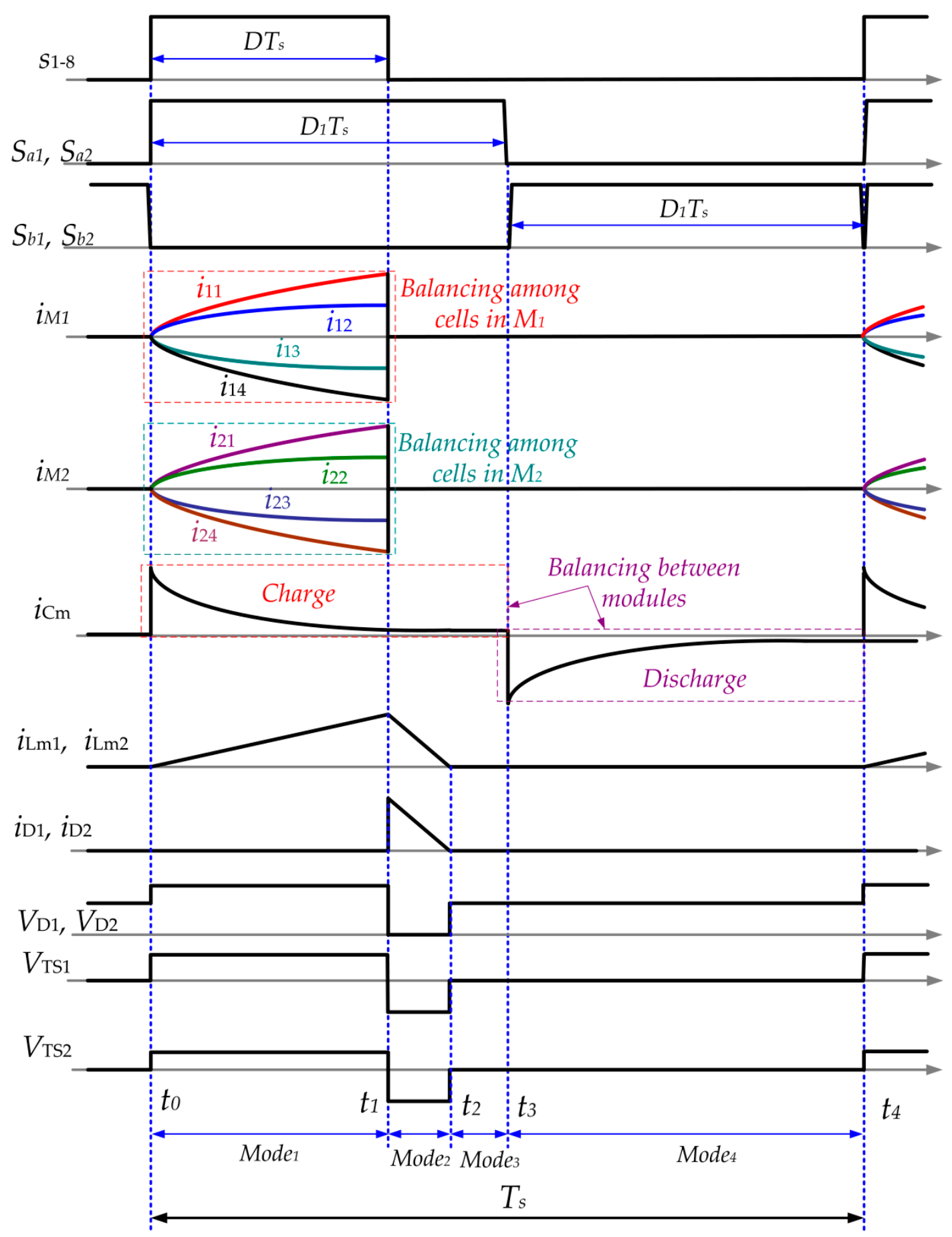

Figure 9. Operational waveforms of the proposed modular cell balancing circuit (MCBC).

2. Operational principle

The operational principle of the proposed MCBC is similar to that of the MWTFC and the SCC individually. In particular, the switches in the MWTFC and the SCC are driven by two fixed duty ratios $(D)$ and $\left(D_{1}\right)$, respectively. In order to simply analyze operating modes for the circuit, the following assumptions are made:

- $\quad$ All the switches, capacitor, diodes and transformer are ideal.

- $\quad$ Each module contains four cells. 
- The relationship among voltage of the battery cells is arranged in decreasing order from $\mathrm{Cell}_{11}$ $\left(V_{\text {cell11 }}\right)$ to $\mathrm{Cell}_{24}\left(V_{\text {cell24 }}\right)$, and $V_{\text {cell11 }}>V_{\text {cell12 }}>V_{\text {aver1 }}>V_{\text {cell13 }}>V_{\text {cell14 }}>V_{\text {cell21 }}>V_{\text {cell22 }}>V_{\text {aver2 }}$ $>V_{\text {cell23 }}>V_{\text {cell24 }}$ (the module 1 voltage: $V_{\mathrm{M} 1}=V_{\text {Cell11 }}+V_{\text {Cell12 }}+V_{\text {Cell13 }}+V_{\text {Cell14 }}$; the average voltage of $M_{1}: V_{\text {aver1 }}=V_{\mathrm{M} 1} / 4$; the module 2 voltage: $V_{\mathrm{M} 2}=V_{\text {Cell21 }}+V_{\text {Cell22 }}+V_{\text {Cell23 }}+V_{\text {Cell24 }}$; the average voltage of $\left.M_{2}: V_{\text {aver2 }}=V_{\mathrm{M} 2} / 4 ; V_{\mathrm{M} 1}>V_{\mathrm{M} 2}\right)$.

There are four operating modes during one switching period $\left(T_{\mathrm{s}}\right)$ of the proposed MCBC. These modes based on the switching states of the primary side switches $\left(S_{11}, S_{12}, S_{13}, S_{14}, S_{21}, S_{22}, S_{23}, S_{11}\right.$, and $\left.S_{24}\right)$ in the intra-module balancer and the switches $\left(S_{\mathrm{a} 1}, S_{\mathrm{a} 2}\right.$, and $\left.S_{\mathrm{b} 1}, S_{\mathrm{b} 2}\right)$ in the outer-module balancer. The theoretical waveforms and operating modes of the proposed circuit are shown in Figures 9 and 10, respectively.

Mode $1\left[t_{0}, t_{1}\right]$ (see Figure 10a): At $t_{1}$, eight switches in intra-module balancers (module 1: $S_{11}$, $S_{12}, S_{13}, S_{14}$; module 2: $S_{21}, S_{22}, S_{23}, S_{24}$ ) and $S_{\mathrm{a} 1}, S_{\mathrm{a} 2}$ are turned on, while $S_{\mathrm{b} 1}, S_{\mathrm{b} 2}$ are turned off simultaneously, as shown in Figure 9. In this mode, the energy is transferred from a high voltage level cell to a low level one inside each module through two MWTs $\left(T_{1}\right)$ and $\left(T_{2}\right)$, respectively.

$V_{\text {Cell11 }}, V_{\text {Cell12 }}$ are higher than $V_{\text {aver1 }}, V_{\text {Cell13 }}, V_{\text {Cell14 }}$ in $M_{1}$, and $V_{\text {Cell21 }}, V_{\text {Cell22 }}$ are higher than $V_{\text {aver2 }}, V_{\text {Cell23 }}, V_{\text {Cell24 }}$ in $M_{2}$. Therefore, $i_{11}, i_{12}$ and $i_{21}, i_{22}$ flow from cells to $T_{1}, T_{2}$, respectively, and $i_{13}$, $i_{14}$ and $i_{23}, i_{24}$ flow from $T_{1}, T_{2}$ to the battery cells. This means that, in module 1 , the electric charges in $\mathrm{Cell}_{11}, \mathrm{Cell}_{12}$ are transmitted to $\mathrm{Cell}_{13}, \mathrm{Cell}_{14}$, and in module 2, the electric charges in $\mathrm{Cell}_{21}, \mathrm{Cell}_{22}$ are transmitted to $\mathrm{Cell}_{23}, \mathrm{Cell}_{23}$.

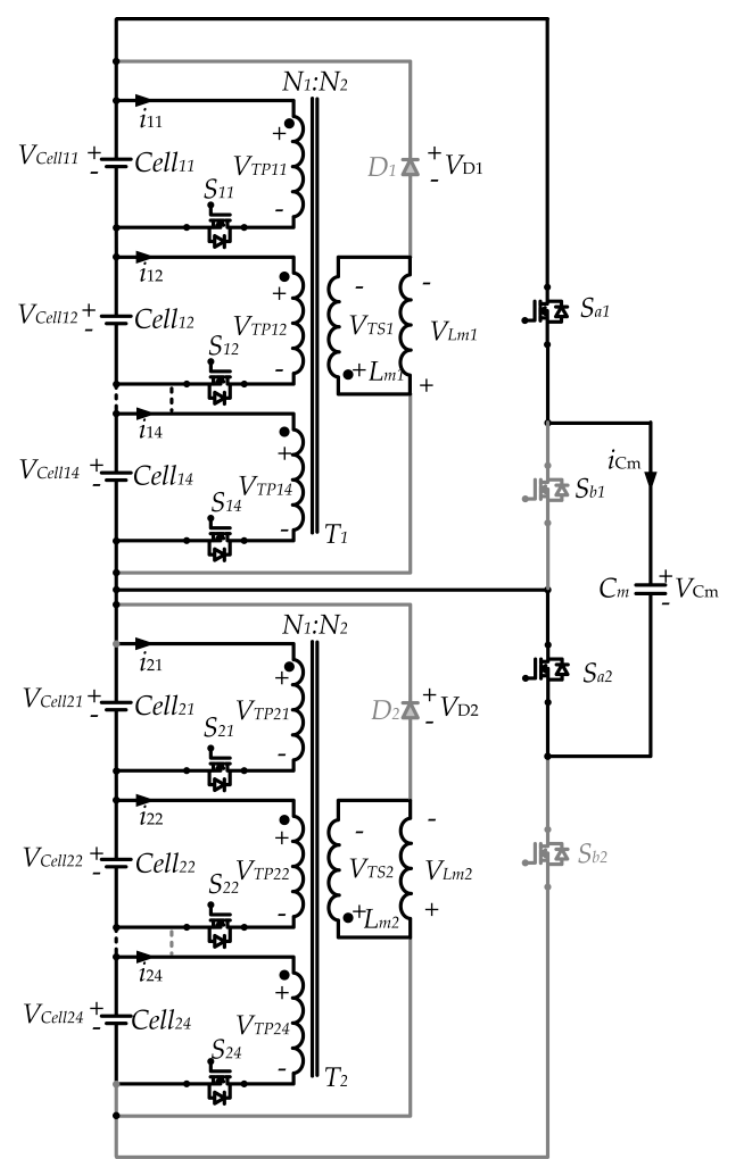

(a)

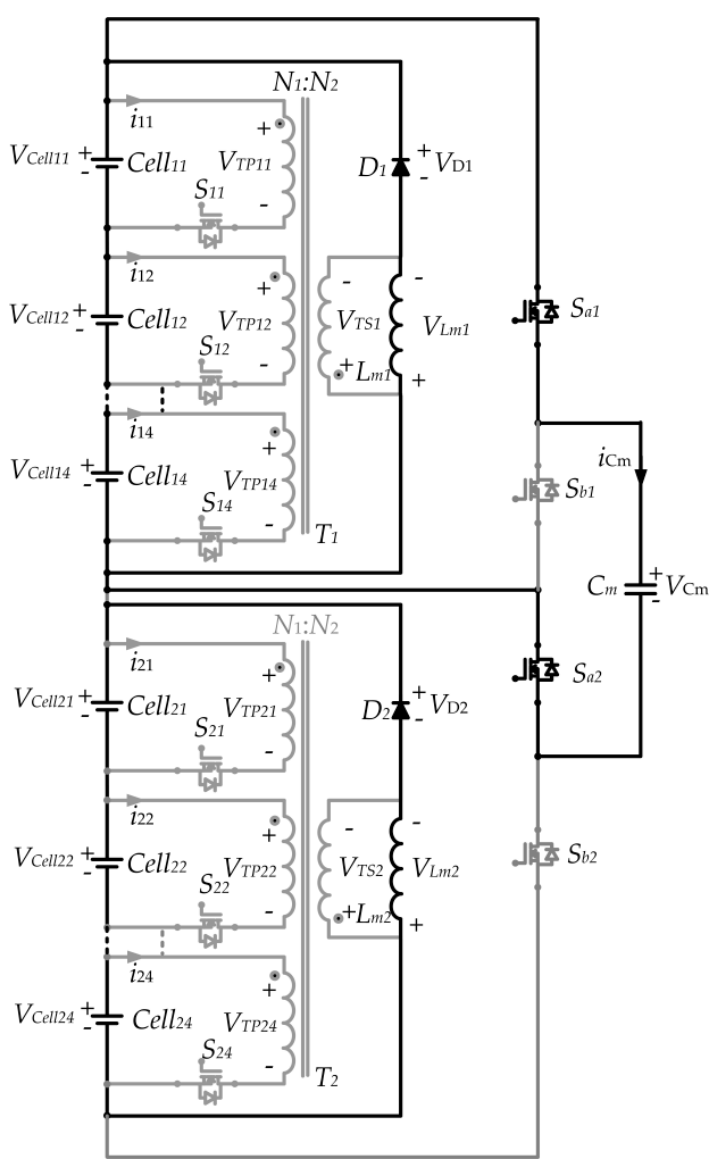

(b)

Figure 10. Cont. 


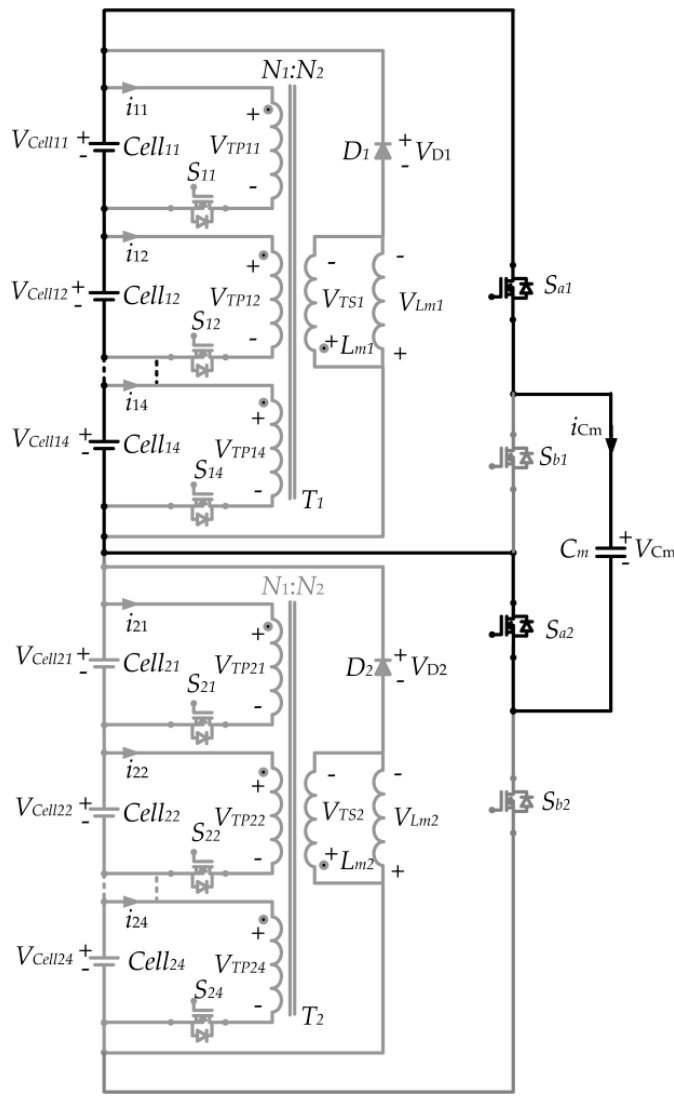

(c)

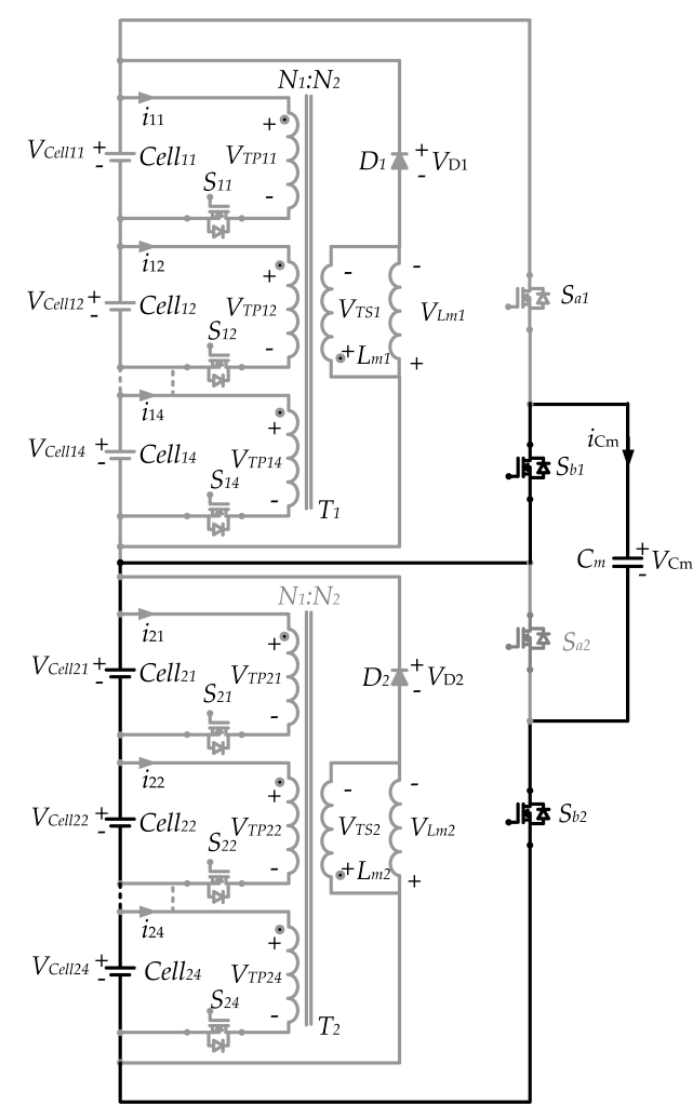

(d)

Figure 10. Operating modes of the proposed MCBC: (a) Mode 1; (b) Mode 2; (c) Mode 3; (d) Mode 4.

At the same time, $S_{\mathrm{a} 1}$ and $S_{\mathrm{a} 2}$ conduct, so the $C_{\mathrm{m}}$ will be charged by the $V_{\mathrm{M} 1}$ through the $S_{\mathrm{a} 1}$ and $S_{\mathrm{a} 2}$ so that the $V_{\mathrm{Cm}}$ increases gradually to a steady state period. The instantaneous voltage and current of the balancing capacitor in this mode can be given by Equations (14) and (15).

$$
\begin{gathered}
v_{C m}(t)=\left(V_{M 1}-V_{C \text { min }}\right) \cdot\left(1-e^{\frac{-t}{R_{C h} \cdot C_{m}}}\right)+V_{C \text { mmin }} \\
i_{C m}(t)=\frac{V_{M 1}-V_{C \text { min }}}{R_{C h}} e^{\frac{-t}{R_{C h} \cdot C_{b m}}}
\end{gathered}
$$

Mode $2\left[t_{1}, t_{2}\right]$ (see Figure 10b): At $t_{1}$, eight switches in the intra-modules balances are turned off simultaneously, as shown in Figure 9. The voltages across $L_{\mathrm{m} 1}$ and $L_{\mathrm{m} 2}$ are negative as expressed by Equations (16) and (17). The diodes $D_{1}$ and $D_{2}$ conduct. Then, $V_{\mathrm{D} 1}, V_{\mathrm{D} 2}$ become zero because $D_{1}$, $D_{2}$ are ideal devices. The $L_{\mathrm{m} 1}$ and $L_{\mathrm{m} 2}$ are reset through the secondary diodes $D_{1}, D_{2}$ resulting in a decrease of the magnetizing currents of transformers 1 and $2\left(i_{\mathrm{Lm} 1}\right.$ and $\left.i_{\mathrm{Lm} 2}\right)$.

$$
\begin{aligned}
& V_{L m 1}=-V_{M 1} \\
& V_{L m 2}=-V_{M 2}
\end{aligned}
$$

Mode $3\left[t_{2}, t_{3}\right]$ (see Figure 10c): Mode 3 starts when the currents through the magnetizing inductance of two transformers $\left(i_{\mathrm{Lm} 1}\right)$ and $\left(i_{\mathrm{Lm} 2}\right)$ are equal to zero. No current flows in the MWTs from $t_{2}$ to $t_{3}$.

Mode $4\left[t_{3}, t_{4}\right]$ (see Figure 10d): At $t_{3}$, the $S_{\mathrm{a} 1}, S_{\mathrm{a} 2}$ are turned off, and the $S_{\mathrm{b} 1}, S_{\mathrm{b} 2}$ starts to be turned on as shown in Figure 9. The voltage $V_{\mathrm{Cm}}$ is higher than the $V_{M 2}$ such that the energy of $C_{\mathrm{m}}$ is in a 
discharging condition. Module 2 receives stored energy in $C_{\mathrm{m}}$ gradually. The instantaneous voltage and current of the module balancing capacitor in this mode are respectively given in Equations (18) and (19). At $t_{4}$, this operating mode is finished and returns to mode 1 in the next switching period.

$$
\begin{gathered}
v_{C m}(t)=v_{C \text { mmin }}-\left(v_{C \text { mmax }}-v_{M 2}\right) \cdot\left(1-e^{\frac{-t}{R_{d i s} \cdot C_{m}}}\right) \\
i_{C m}(t)=-\frac{v_{C \text { mmax }}-v_{M 2}}{R_{d i s}} e^{\frac{-t}{R_{d i s} \cdot C_{m}}}
\end{gathered}
$$

According to the analysis of the above operation modes, it can be seen that the MWTFC-based intra-module balancer and SCC-based outer-module balancer work separately. The energy is transferred from a high to a low level of both the cells in each module and the modules simultaneously. Thus, the short balancing time, simple control scheme and the low mismatch between the leakage inductances can be obtained due to a small number of cells.

\section{Experimental Setup}

In this paper, the MCBC was experimentally verified to validate the theoretical operation of the proposed topology. The experimental setup consisting of two parts is illustrated in Figure 11, and circuit components are shown in more detail in Table 1. The first part is the designed MCBC, which consists of twelve switches, two diodes, one module balancing capacitor $C_{\mathrm{m}}$, and two multi-winding transformers. An IM 3533 LCR meter was used to measure the magnetizing and leakage inductances of two transformers. The second part is the available equipment such as power supply, voltage recorder, oscilloscope and DSP board. The voltage recorder (i.e., YOKOGAWA-GP10) was used to measure and record the voltage balancing process of eight cells, and the battery cell used Lithium-ion cell LIR17335-PCM C5264RR (2/3 A 3.7 V $700 \mathrm{mAh}$ ). Gate driver voltage $V_{\mathrm{gs}}$ of the switches such as $S_{11}$, $S_{24}, S_{\mathrm{a} 1}$, and $S_{\mathrm{b} 1}$ is shown in Figure 12. Therein, the duty ratio $(D)$ of signals to power switches in the intra-module balancers is $37.5 \%$, and the duty ratio $\left(D_{1}\right)$ of the signal to switches $S_{\mathrm{a} 1}, S_{\mathrm{b} 1}$ is $50 \%$ of one switching period where the $S_{\mathrm{a} 1}$ and $S_{\mathrm{b} 1}$ are complementary, and switching frequency of $f$ and $f_{1}$ are set for $40 \mathrm{kHz}$.

\begin{tabular}{|c|c|c|c|}
\hline \multicolumn{3}{|c|}{ Parameter } & Value \\
\hline \multirow{8}{*}{ Cell balancing circuit } & \multicolumn{2}{|c|}{ Twelve MOSFETs } & IPP023N10N5 \\
\hline & \multicolumn{2}{|c|}{ Two diodes } & DO-204AC (DO-15) \\
\hline & \multirow{4}{*}{\multicolumn{2}{|c|}{$\begin{array}{c}\text { Two Transformers } \\
\text { (Four primary/One secondary windings) }\end{array}$}} & Core: EER2828N \\
\hline & & & $N_{1}: N_{2}=1: 1$ \\
\hline & & & $L_{\mathrm{m} 1}=1.88 \mathrm{mH} ; L_{\mathrm{m} 2}=1.83 \mathrm{mH}$ \\
\hline & & & $\begin{array}{l}L_{l k 11}=1.87 \mu \mathrm{H} ; L_{l k 12}=1.95 \mu \mathrm{H} ; \\
L_{l k 13}=3.39 \mu \mathrm{H} ; L_{l k 14}=1.94 \mu \mathrm{H} ; \\
L_{l k 21}=2.30 \mu \mathrm{H} ; L_{l k 22}=1.99 \mu \mathrm{H} ; \\
L_{l k 23}=2.00 \mu \mathrm{H} ; L_{l k 24}=1.98 \mu \mathrm{H} ;\end{array}$ \\
\hline & Balancir & capacitor & $700 \mu \mathrm{F}$ \\
\hline & Gat & Iriver & UCC27519A-Q1 \\
\hline \multirow{3}{*}{ Battery string } & \multirow{3}{*}{$\begin{array}{l}\text { Eight Lithium-ion } \\
\text { cells }\end{array}$} & Nominal capacity & $700 \mathrm{mAh}$ \\
\hline & & Nominal voltage & $3.7 \mathrm{~V}$ \\
\hline & & Weight & $18 \mathrm{~g}$ \\
\hline Cell voltage recorder & Series-connected & ell string recorder & YOKOGAWA-GP10 \\
\hline \multirow{2}{*}{ Controller } & \multicolumn{2}{|c|}{ Switching frequency } & $40 \mathrm{kHz}$ \\
\hline & \multicolumn{2}{|c|}{ Digital controller } & TMS320F28335 \\
\hline
\end{tabular}

Table 1. The parameters of the proposed balancing circuit. 


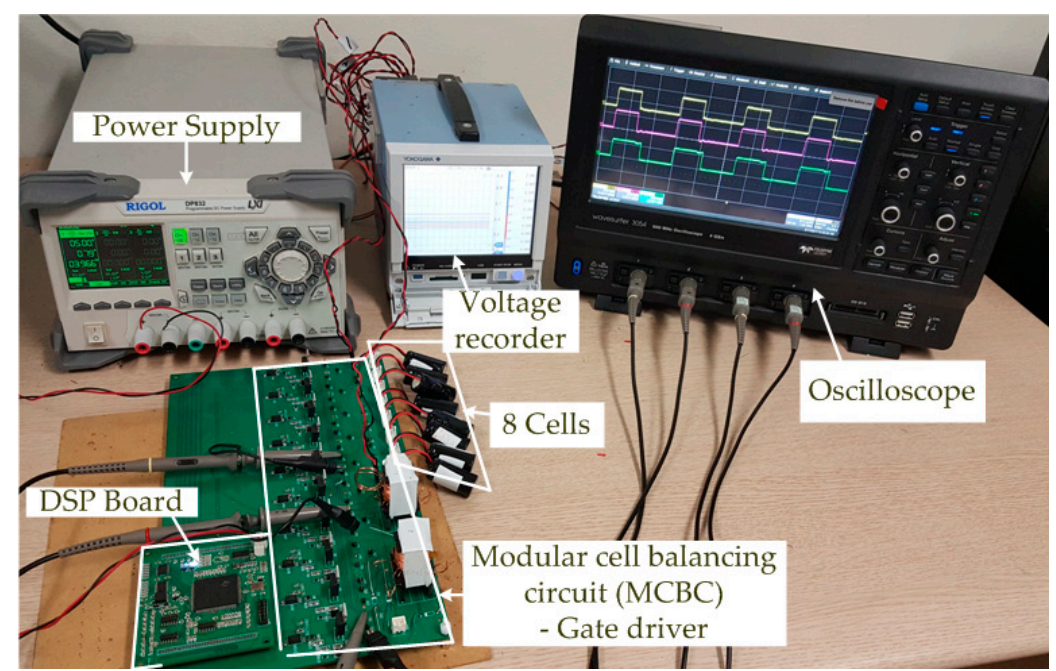

Figure 11. A prototype of the modular cell balancing circuit and experimental setup.

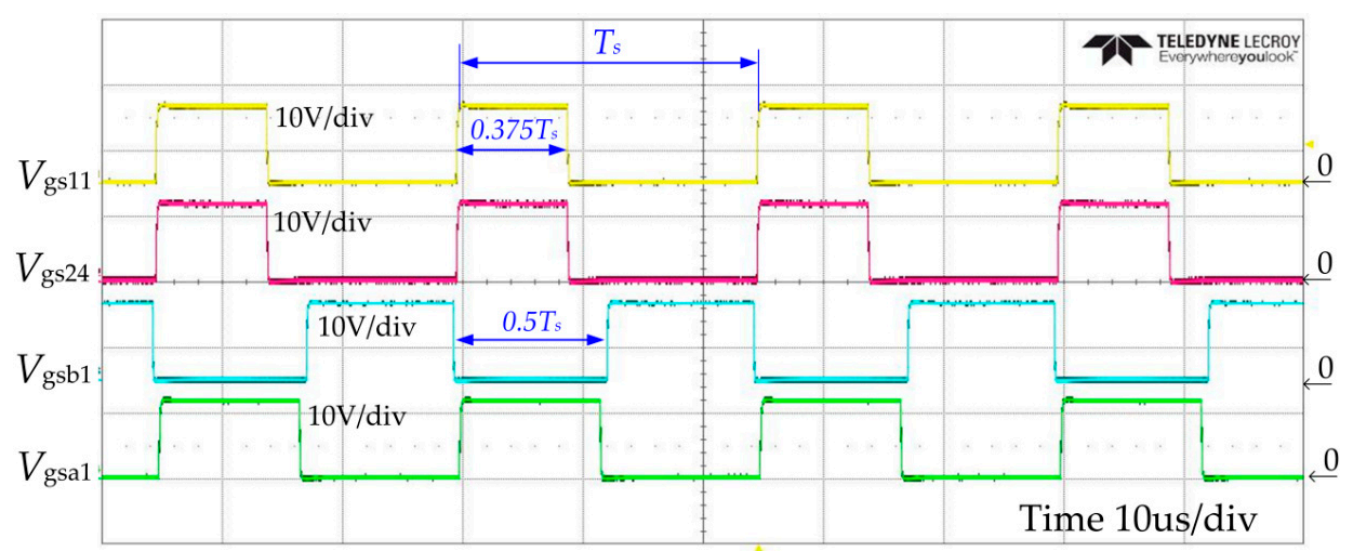

Figure 12. PWM Signals of switches $S_{11}, S_{24}, S_{a 1}$ and $S_{a 2}$.

In this work, the experiment in three cases of initial different voltage arrangements of the cells is performed. The voltages of the cells are set as follows. Case 1: the voltages of eight cells are arranged in decreasing order from $\mathrm{Cell}_{11}$ (i.e., $\left.V_{\text {cell11 }}\right)$ to $\mathrm{Cell}_{24}$ (i.e., $V_{\text {cell24 }}$ ); Case 2: $V_{\text {cell11 }}>V_{\text {cell21 }}>V_{\text {cell12 }}>$ $V_{\text {cell22 }}>V_{\text {cell13 }}>V_{\text {cell23 }}>V_{\text {cell14 }}>V_{\text {cell24, }}$ and case 3: the initial voltage of the cells is set randomly, as shown in detail in Table 2.

Table 2. The initial voltages of the cells for the experiment.

\begin{tabular}{|c|c|c|c|c|c|c|}
\hline \multirow[b]{2}{*}{$\begin{array}{l}\text { Battery } \\
\text { Cells }\end{array}$} & \multicolumn{2}{|c|}{ Case 1} & \multicolumn{2}{|c|}{ Case 2} & \multicolumn{2}{|c|}{ Case 3} \\
\hline & $\begin{array}{c}\text { Initial Cell } \\
\text { Voltages [V] }\end{array}$ & $\begin{array}{c}\text { Module } \\
\text { Voltage [V] }\end{array}$ & $\begin{array}{c}\text { Initial Cell } \\
\text { Voltages [V] }\end{array}$ & $\begin{array}{c}\text { Module } \\
\text { Voltage [V] }\end{array}$ & $\begin{array}{c}\text { Initial Cell } \\
\text { Voltages [V] }\end{array}$ & $\begin{array}{c}\text { Module } \\
\text { Voltage [V] }\end{array}$ \\
\hline $\mathrm{Cell}_{11}$ & 3.880 & \multirow{4}{*}{$V_{\mathrm{M} 1}=15.183$} & 3.896 & \multirow{4}{*}{$V_{\mathrm{M} 1}=14.862$} & 3.871 & \multirow{4}{*}{$V_{\mathrm{M} 1}=14.906$} \\
\hline $\mathrm{Cell}_{12}$ & 3.857 & & 3.773 & & 3.585 & \\
\hline $\mathrm{Cell}_{13}$ & 3.745 & & 3.666 & & 3.661 & \\
\hline $\mathrm{Cell}_{14}$ & 3.701 & & 3.527 & & 3.789 & \\
\hline $\mathrm{Cell}_{21}$ & 3.652 & \multirow{4}{*}{$V_{\mathrm{M} 2}=14.291$} & 3.816 & \multirow{4}{*}{$V_{\mathrm{M} 2}=14.575$} & 3.744 & \multirow{4}{*}{$V_{\mathrm{M} 2}=14.437$} \\
\hline $\mathrm{Cell}_{22}$ & 3.604 & & 3.695 & & 3.529 & \\
\hline $\mathrm{Cell}_{23}$ & 3.543 & & 3.574 & & 3.674 & \\
\hline $\mathrm{Cell}_{24}$ & 3.492 & & 3.490 & & 3.490 & \\
\hline $\mathrm{V}_{\Sigma \text { Cell }}[\mathrm{V}]$ & \multicolumn{2}{|c|}{29.474} & \multicolumn{2}{|c|}{29.437} & \multicolumn{2}{|c|}{29.343} \\
\hline
\end{tabular}




\section{Results and Discussion}

Figure 13 shows experimental results of the proposed circuit for three cases. A higher and a lower voltage of the cells inside the module tend towards each other and all cells tend to the average voltage value of the cells in series. The proposed balancing circuit indeed demonstrates the balancing trend since the voltages of cells gradually reach a balanced state. Furthermore, the results on the different cases indicate that the cells achieved the balanced state regardless of the various arrangement of the initial voltage of all the cells.

Energy efficiency of the balancing circuit can be used Equation (20) [16] as follows:

$$
\eta=\frac{E_{\text {residue }}}{E_{\text {imbalance }}}=\frac{\sum_{i=1}^{N} 0.5 C_{\text {cell }}\left(V_{\text {Celli_end }}^{2}-V_{\text {min }}^{2}\right)}{\sum_{i=1}^{N} 0.5 C_{\text {cell }}\left(V_{\text {Celli_start }}^{2}-V_{\text {min }}^{2}\right)}
$$

where $E_{\text {imbalance }}$ and $E_{\text {residue }}$ are unbalanced energy before cell balancing and remaining energy of $E_{\text {imbalance }}$ after cell balancing, respectively. $C_{\text {cell }}$ is the capacitance of the battery cell; $V_{\text {celli_start }}$ and $V_{\text {celli_end }}$ are the cell voltage of the $i$ th cell before and after balancing, respectively; $V_{\min }$ and $N$ are the initial lowest voltage and number of cells, respectively.

In case 1 (see Figure 13a), the highest voltage is $3.880 \mathrm{~V}$, the lowest voltage is 3.492 , and the initial maximum voltage difference is $388 \mathrm{mV}$, and then the difference reduces to $115 \mathrm{mV}$ after the balancing circuit runs for $300 \mathrm{~min}$, and from (20) and experimental data and results, the energy efficiency is $\eta_{1}=76.27 \%$. Similarly, in case 2 (see Figure 13b) and case 3 (see Figure 13c), the maximum voltage difference among the cells reduces from $406 \mathrm{mV}$ to $112 \mathrm{mV}$ and from $381 \mathrm{mV}$ to $86 \mathrm{mV}$ after the balancing circuit runs for $150 \mathrm{~min}$, and $200 \mathrm{~min}$, and $\eta_{2}=83.31 \%$ and $\eta_{3}=81.74 \%$, respectively. The energy efficiency in three cases is different due to the difference in balancing time. If the balancing time is short, the energy efficiency will increase. In reality, the initial different voltage arrangement of the cells is set as in cases 2 or 3 . These are the cases with the highest energy efficiency of the circuit.

From the experimental results in Figure 13, we can see that there are minor residual voltage mismatches because the leakage inductances of the transformer were not uniform, as shown in Table 1 . $L_{\mathrm{lk} 13}$ of the transformer was larger than others; hence, the current $i_{13}$ was smaller. In other words, the balance of the Cell $_{13}$ was slower than others, as shown in Figure 13a.

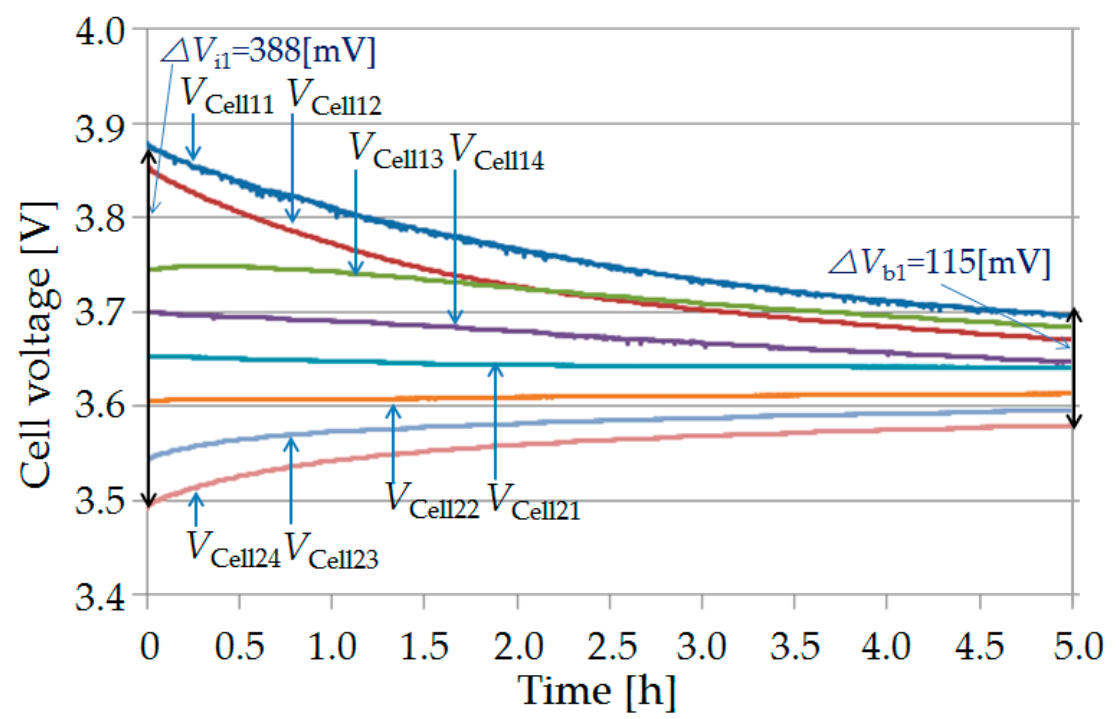

(a)

Figure 13. Cont. 


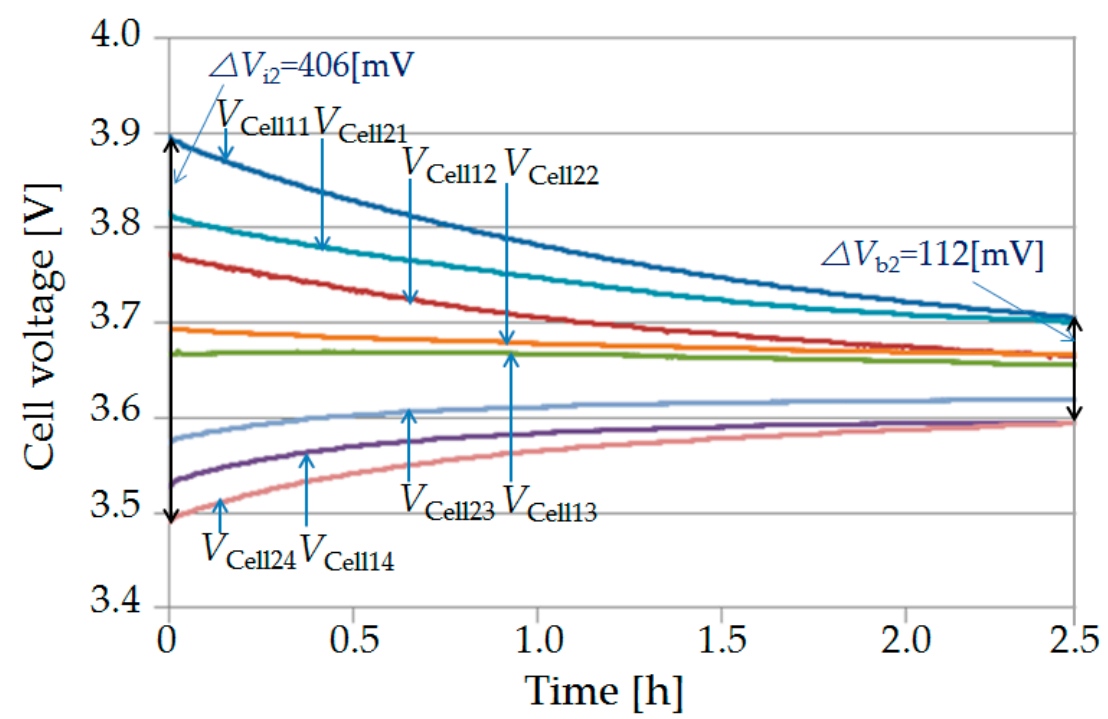

(b)

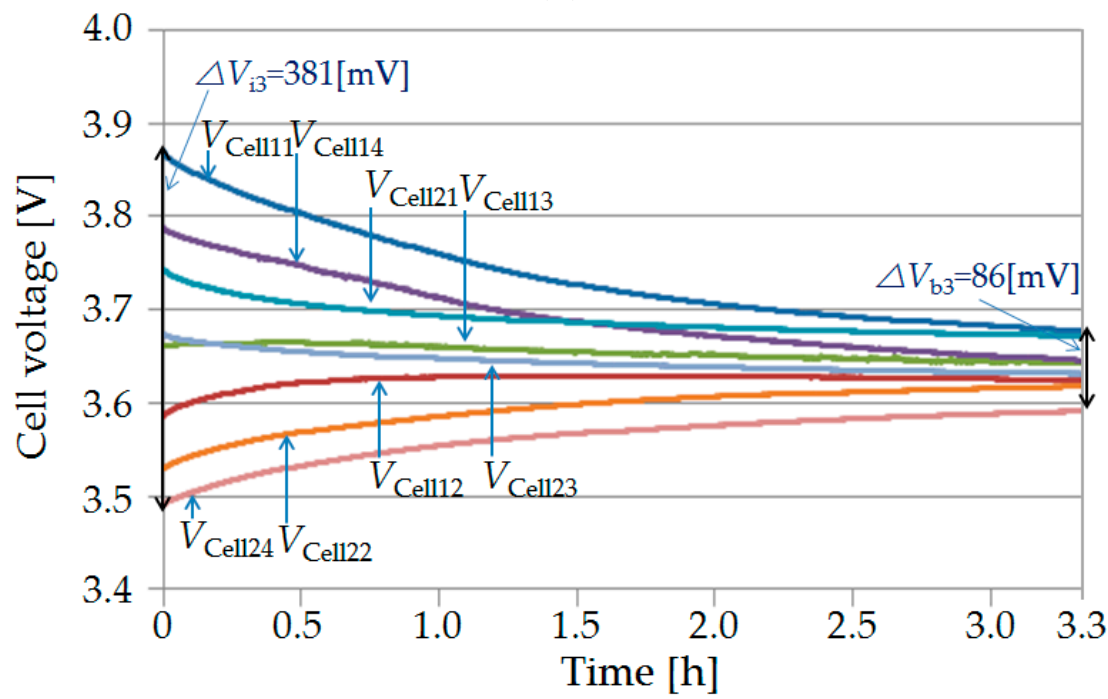

(c)

Figure 13. The experimental voltage results of eight cells: (a) Case 1; (b) Case 2; (c) Case 3.

According to Table 2, the initial maximum voltage difference of the cells in three cases is a minor divergence of approximately $25 \mathrm{mV}$. In addition, the total of the cell voltages is approximate. In particular, cases 1, 2 and 3 are $29.474 \mathrm{~V}, 29.437 \mathrm{~V}$ and $29.343 \mathrm{~V}$, respectively. However, the balancing time for three cases is more different due to dependence on voltage unbalance between the $M_{1}$ and $M_{2}$, like the SCC-based balancer theory in Section 2.1. In detail, the initial voltage differences between the $M_{1}$ and $M_{2}$ for case 1 , case 2, and case 3 are $892 \mathrm{mV}, 287 \mathrm{mV}$, and $381 \mathrm{mV}$, the balancing times are $300 \mathrm{~min}, 150 \mathrm{~min}$, and $200 \mathrm{~min}$, respectively. The total voltage and the initial maximum different voltage of the cells are approximate; the voltage difference of the modules is different due to the arrangement of all cells. On the order hand, the balancing time of the circuit depends on the arrangement of the initial voltage of all cells. In order to more clearly show the reduction in the difference of the initial and balanced state voltage, the initial and balanced state voltages of cases 1,2 and 3 are shown in Figure $14 a-c$, respectively. 


\section{$\mathbb{Z}$ Initial voltages $\mathbb{B}$ Balanced state}
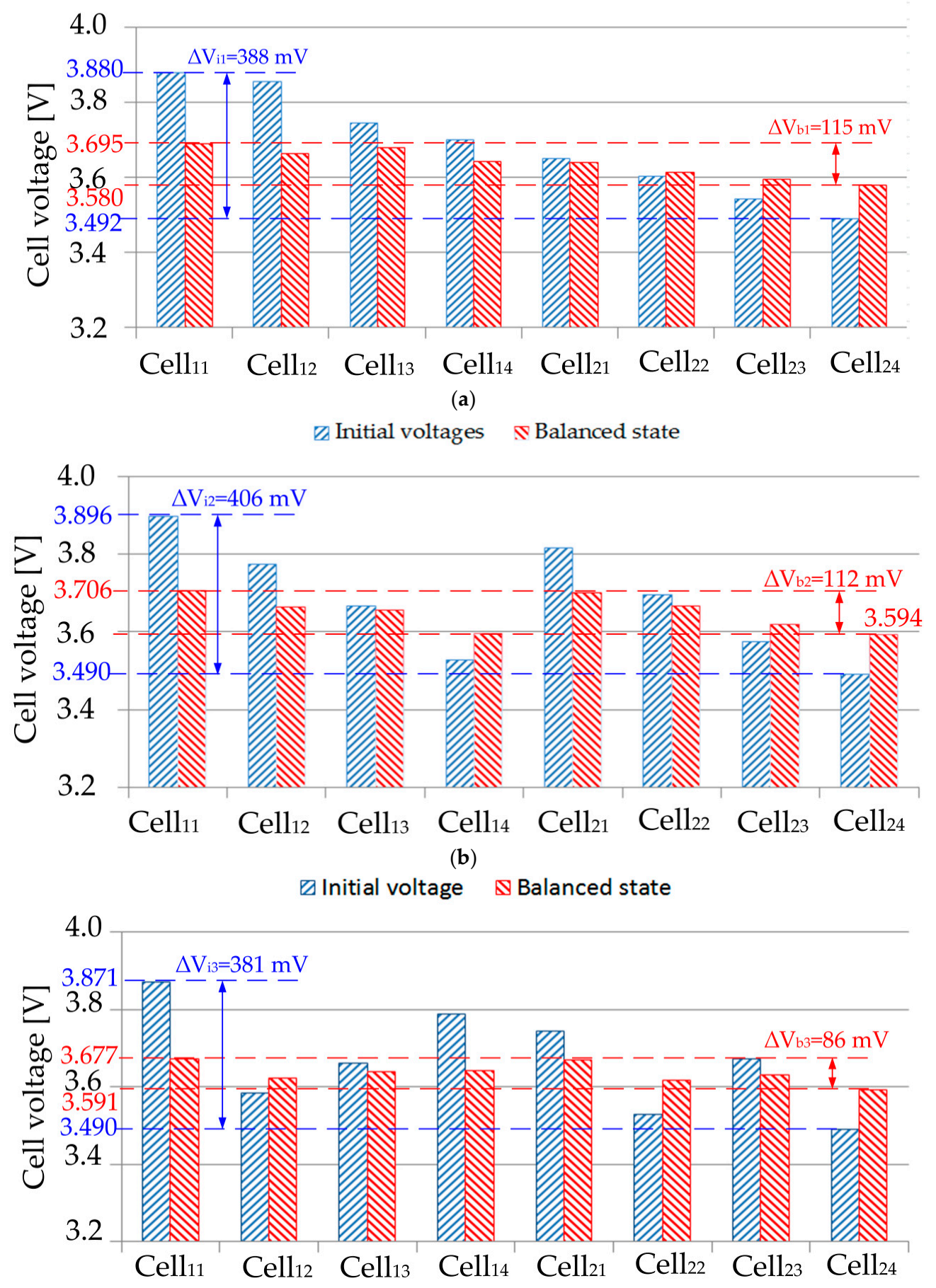

(c)

Figure 14. Initial and balanced state voltages: (a) Case 1; (b) Case 2; (c) Case 3.

In this work, three different cases, in which initial maximum voltage difference and the total voltage of the cells are approximate, are tested to consider the correlation between the voltage difference of modules and balancing time in estimating the balancing time of the circuit. In case 1 , the voltage difference of two modules is $892 \mathrm{mV}$, the balancing time is $300 \mathrm{~min}$, and each $1 \mathrm{mV}$ difference needs a time of approximately $0.336 \mathrm{~min}$ for balancing. Similarly, cases 2 and 3 are 0.523 and $0.426 \mathrm{~min}$, respectively. It shows that the voltage difference between the $M_{1}$ and $M_{2}$ increases, resulting in the 
increased balancing time. However, the balancing time will slightly decrease as shown in Figure 15 . It can be estimated the balancing time in the range segment $\mathrm{AC}$ for other experiments with the initial maximum voltage difference and the total voltage of the cells like this experiment.

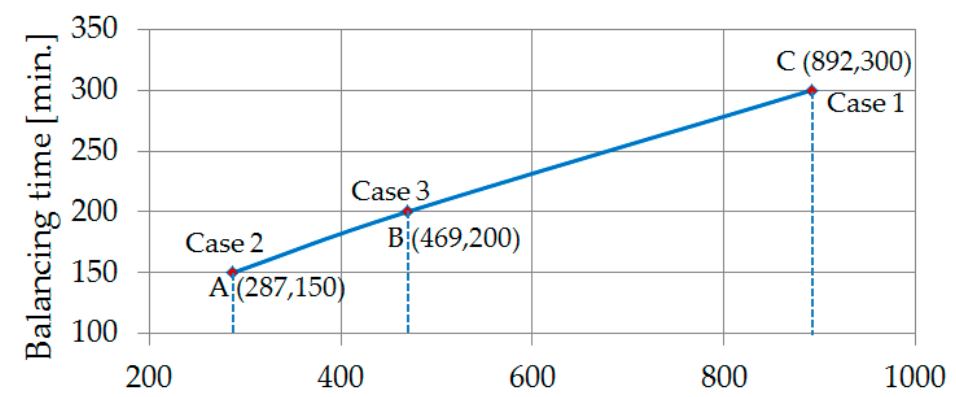

Figure 15. The balancing time vs the voltage difference between two modules.

In order to evaluate a voltage drop of the cells after balancing, the total voltage of before and after balancing can be evaluated by the percentage of the voltage drop, which can be expressed by the efficiency as follows.

$$
\eta_{V}=\frac{\sum_{j=1}^{N} V_{\text {Cellj_start }}-\sum_{j=1}^{N} V_{\text {Cellj_end }}}{\sum_{j=1}^{N} V_{\text {Cellj_start }}} \times 100 \%,
$$

where $\sum_{j=1}^{N} V_{\text {Cellj_start }}$ and $\sum_{j=1}^{N} V_{\text {Cellj_end }}$ are the total voltage of eight cells before and after balancing, respectively. $N$ is the number of the cells in the SCBS.

From (21) and experimental data and results, the percentage of the voltage drop of three cases can be plotted as shown in Figure 16. They are displayed in the time range from 0 to $150 \mathrm{~min}$ (i.e., balancing time of the case 2). The percentage of the highest voltage drop of three cases is $0.8 \%$ and there is a minor difference. The voltage drop is due to the transmission energy of the cells through the transformers, capacitor etc.

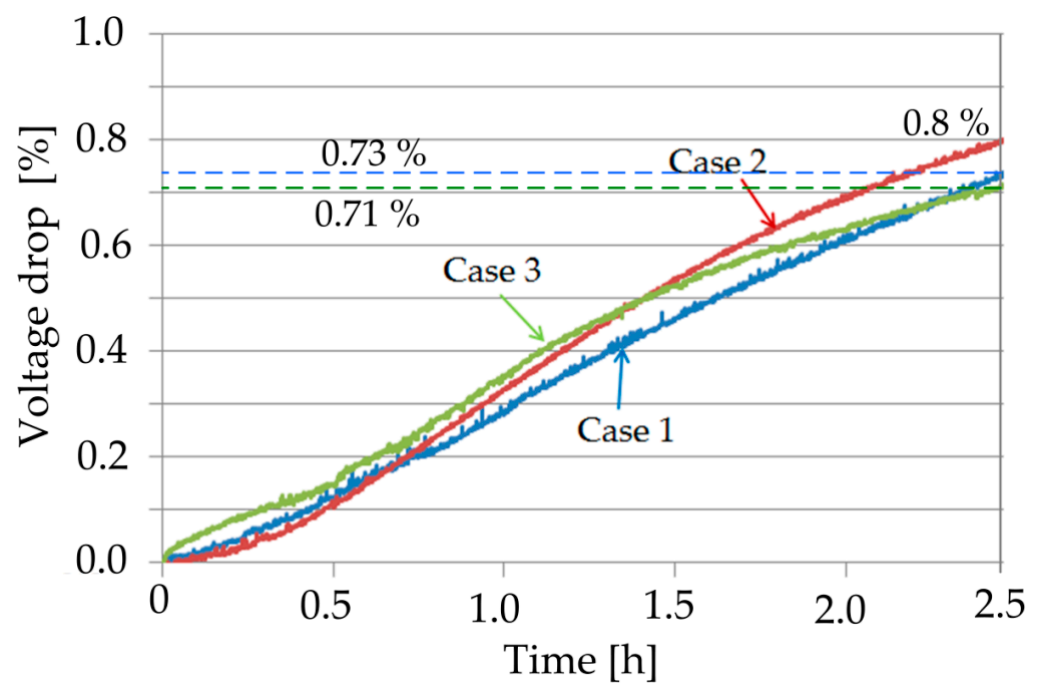

Figure 16. The percentage of the voltage drop of three cases $(0-2.5 \mathrm{~h})$.

\section{Comparison with Conventional Balancing Methods}

Table 3 shows the comparison of the proposed topology and existing topologies in terms of a number of required components within the case of $n$ cells connected in series. A buck-boost 
converter-based balancing topology $[12,14,36-38]$ or switched capacitor converter-based balancing topology $[11,15,22,26,27,30]$ can be constructed with a reasonable number of components. However, the energy transfer of these topologies is limited between two adjacent cells (i.e., cell to cell balancing) when a large number of cells in SCBS increases (i.e., approximately 80 or more cells) resulting in relatively slow balancing speed and low balancing efficiency. Moreover, the buck-boost converter-based balancers need intelligent control and a large number of the switches resulting in relative complex control scheme and high cost. In the MWT-based balancing topologies $[10,17,18]$, the multi-winding transformer needs to be considered as the main drawback due to not only the stringent requirement for parameter matching for the turns ratio but also the requirement to change the number of secondary windings. These lead to a mismatch between the leakage inductance that caused a charge imbalance drawback by itself. The circuit used the voltage multiplier to balance the cells [34]. The voltage multiplier circuit used the diodes and the capacitors. Therefore, there is no leakage mismatch issue. However, this circuit depends on the impedance of the capacitors. If $R_{\text {eqi }}$ and $V_{\mathrm{D}}$ are not unified, they will cause a residual voltage imbalance. Additionally, the larger capacity of the capacitor results in a longer balancing time. The balanced voltages of the cells indicate a reduction much lower than the average voltage of the cells.

In this study, the proposed balancing topology is constructed with the existing transformer by increasing the number of the transformers. The proposed circuit consists of the MWTFC-based intra-module balances and SCC-based outer-module balancer in transferring the energy from a high to a low level of both the cells in each module and the modules simultaneously. In other words, the intraand outer-module balancers deal with $N$ cells in each module and $M$ modules, respectively. However, in the conventional methods, one MWTFC-based balancer or one SCC-based balancer should equalize $N \times M$ cells. Hence, the proposed circuit deals with a small number of the cells, so that a balancing time for one MWTFC-based balancer can be a significant reduction. When compared to conventional balancing topologies using the MWTFC or switched capacitor converter, the proposed balancing topology offers some advantages as follows.

- Basically, the proposed balancing circuit has some advantages originally found in the MWTFC-based balancer and SCC-based balancer such as the repudiation of the voltage sensors for the feedback control loop, simple control scheme.

- The MWTFC-based balancer is applied to a small number of cells. Therefore, the problem of mismatched leakage inductance can be minimized.

- The voltage stress of switches is low by applying the SCC-based balancer to the outer-module balancer.

- The number of cells in series can be easily extended.

Table 3. Comparison of the proposed and conventional topologies in a number of components.

\begin{tabular}{|c|c|c|c|c|c|c|}
\hline \multirow{2}{*}{\multicolumn{2}{|c|}{ Topology }} & \multicolumn{5}{|c|}{ No. of the Components } \\
\hline & & Switch & D & C & $\mathbf{L}$ & Transformer \\
\hline \multirow{4}{*}{$\begin{array}{l}\text { Switched capacitor } \\
\text { converter }\end{array}$} & Basic SCC [22] & $2 \mathrm{n}$ & - & $\mathrm{n}-1$ & - & - \\
\hline & Double-Tiered SCC [26] & $2 \mathrm{n}$ & - & $2 n-3$ & - & - \\
\hline & Single SCC [30] & $n+5$ & - & 1 & - & - \\
\hline & Quasi-Resonant SCC [38] & $2 \mathrm{n}$ & - & $\mathrm{n}-1$ & $\mathrm{n}-1$ & - \\
\hline \multirow{2}{*}{ Buck-boost Converter } & Basis topology [12] & $2(n-1)$ & - & - & $\mathrm{n}-1$ & - \\
\hline & Cuk converter [36] & $2(\mathrm{n}-1)$ & - & $\mathrm{n}-1$ & $2(\mathrm{n}-1)$ & - \\
\hline \multirow{2}{*}{$\begin{array}{l}\text { Multi-winding } \\
\text { transformer }\end{array}$} & Flyback converter [18] & 1 & $\mathrm{n}$ & - & - & 1 (n primary windings) \\
\hline & Forward converter [17] & $\mathrm{n}$ & 1 & - & - & 1 (n primary windings) \\
\hline \multicolumn{2}{|c|}{ Proposed topology } & $n+2 M$ & $\mathrm{M}$ & $\mathrm{M}-1$ & - & $\mathrm{M}(\mathrm{n} / \mathrm{M} \text { primary windings })^{1}$ \\
\hline
\end{tabular}

\section{Conclusions}

A cell balancing topology in combination with MWTFC and SCC has been proposed and experimentally verified in the present paper. The balancing circuit based on the intra-module and 
outer-module balancers has several advantages and overcomes the disadvantages of two conventional circuits. In this balancing topology, the energy of cells in SCBS is transmitted from a high voltage level to a low voltage level in both the cells in each module and the modules by simultaneous intraand outer-module balancers. The main advantages of the proposed MCBC are the elimination of voltage sensors and the simple control scheme. Further, the proposed MCBC can easily extend the number of cells in SCBS. The experimental results for three different cases show that the voltages of all cells in SCBS achieved a balanced state. Furthermore, regardless of the various arrangements of the initial voltage, the voltages of the cells have achieved a balance state. In the balanced state, the energy efficiency of the proposed circuit can reach $83.31 \%$. We have obtained satisfactory results proving that the proposed balancing circuit could be applied for SCBS in electric vehicles.

Author Contributions: Conceptualization, T.M.B. and S.B.R.; Methodology, T.M.B. and S.B.R.; Software, T.M.B.; Validation, T.M.B. and S.B.R.; Formal Analysis, T.M.B. and S.B.R.; Investigation, T.M.B. and S.B.R.; Resources, T.M.B.; Data Curation, T.M.B.; Writing-Original Draft Preparation, T.M.B.; Writing-Review \& Editing, T.M.B., C.-H.K., K.-H.K. and S.B.R.; Visualization, T.M.B., C.-H.K. and K.-H.K.; Supervision, S.B.R.

Funding: This research received no external funding.

Acknowledgments: The authors are extremely thankful to Smart Power System laboratory, Yeungnam University and Power \& Energy System laboratory, Hanyang University for providing necessary information, materials, equipment, and guidance to pursue this research. We would like to express our gratitude to one and all who were directly or indirectly involved in the research results.

Conflicts of Interest: The authors declare no conflict of interest.

\section{Nomenclature}

$\begin{array}{ll}\text { Cell } & \text { battery cell } \\ C & \text { capacitance } \\ D & \text { duty cycle } \\ i & \text { current } \\ L & \text { inductance } \\ S & \text { MOSFET } \\ V & \text { Balancing capacitor voltage } \\ T_{S} & \text { switching period } \\ \text { Subscripts } & \\ \text { aver } & \text { average } \\ \text { cb } & \text { balancing capacitor } \\ \text { cm } & \text { module capacitor } \\ \text { ch } & \text { charge } \\ \text { dis } & \text { discharge } \\ \text { ds } & \text { drain-source } \\ \text { eq } & \text { equivalent } \\ \text { gs } & \text { gate-source } \\ \text { m } & \text { magnetic } \\ \text { min } & \text { minimum } \\ \text { PP } & \text { transformer's primary } \\ \text { TS } & \text { transformer's secondary } \\ \text { Acronyms } & \\ \text { C } & \text { Capacitor } \\ \text { D } & \text { Diode } \\ \text { DSP } & \text { Digital Signal Processor } \\ \text { EV } & \text { electric vehicle } \\ \text { HEV } & \text { Hybrid electric vehicle } \\ \text { IC } & \text { Integrated circuit } \\ \text { M } & \text { Module } \\ & \end{array}$




$\begin{array}{ll}\text { MCBC } & \text { Modular cell balancing circuit } \\ \text { MWT } & \text { Multi-winding transformer } \\ \text { MWTFC } & \text { MWT forward converter } \\ \text { NTC } & \text { Negative Temperature Coefficient } \\ \text { PWM } & \text { Pulse-Width-Modulated } \\ \text { SCBS } & \text { Series-connected Lithium-Ion battery string } \\ \text { SCC } & \text { Switched capacitor circuit } \\ \text { T } & \text { Transformer }\end{array}$

\section{References}

1. Kim, C.H.; Kim, M.Y.; Moon, G.W. A modularized charge equalizer using a battery monitoring ic for series-connected li-ion battery strings in electric vehicles. IEEE Trans. Power Electron. 2013, 28, 3779-3787. [CrossRef]

2. Kim, C.; Member, S.; Kim, M.; Member, S.; Park, H.; Member, A.; Moon, G. A Modularized Two-Stage Charge Equalizer With Cell Selection Switches for Series-Connected Lithium-Ion Battery String in an HEV. IEEE Trans. Power Electron. 2012, 27, 3764-3774. [CrossRef]

3. Park, H.; Member, S.; Kim, C.; Kim, C.; Member, S.; Moon, G.; Lee, J. A Modularized Charge Equalizer for an HEV Lithium-Ion Battery String. IEEE Trans. Ind. Electron. 2009, 56, 1464-1476. [CrossRef]

4. Allègre, A.L.; Bouscayrol, A.; Delarue, P.; Barrade, P.; Chattot, E.; El-Fassi, S. Energy storage system with supercapacitor for an innovative subway. IEEE Trans. Ind. Electron. 2010, 57, 4001-4012. [CrossRef]

5. Panchal, S.; Mathew, M.; Dincer, I.; Agelin-Chaab, M.; Fraser, R.; Fowler, M. Thermal and electrical performance assessments of lithium-ion battery modules for an electric vehicle under actual drive cycles. Electr. Power Syst. Res. 2018, 163, 18-27. [CrossRef]

6. Panchal, S.; Dincer, I.; Agelin-Chaab, M.; Fowler, M.; Fraser, R. Uneven temperature and voltage distributions due to rapid discharge rates and different boundary conditions for series-connected LiFePO4batteries. Int. Commun. Heat Mass Transf. 2017, 81, 210-217. [CrossRef]

7. Lee, Y.; Jeon, S.; Lee, H.; Bae, S. Comparison on cell balancing methods for energy storage applications. Indian J. Sci. Technol. 2016, 9. [CrossRef]

8. Daowd, M.; Omar, N.; van den Bossche, P.; van Mierlo, J. A review of passive and active battery balancing based on MATLAB/Simulink. Int. Rev. Electr. Eng. 2011, 6, 2974-2989. [CrossRef]

9. Bentley, W.F. Cell balancing considerations for lithium-ion battery systems. Twelfth Annu. Batter. Conf. Appl. Adv. 1997, 223-226, 223-226. [CrossRef]

10. Bui, T.; Bae, S. Active Clamped Forward based Active Cell Balancing Converter. Indian J. Sci. Technol. 2015, 8 , 1-6. [CrossRef]

11. Ye, Y.; Cheng, K.W.E. An automatic switched-capacitor cell balancing circuit for series-connected battery strings. Energies 2016, 9, 138. [CrossRef]

12. Wu, T.H.; Moo, C.S.; Hou, C.H. A battery power bank with series-connected buck-boost-type battery power modules. Energies 2017, 10, 650. [CrossRef]

13. Imtiaz, A.M.; Khan, F.H. "Time shared flyback converter" based regenerative cell balancing technique for series connected li-ion battery strings. IEEE Trans. Power Electron. 2013, 28, 5960-5975. [CrossRef]

14. Zeltser, I.; Kirshenboim, O.; Dahan, N.; Peretz, M.M. ZCS resonant converter based parallel balancing of serially connected batteries string. In Proceedings of the 2016 IEEE Applied Power Electronics Conference and Exposition (APEC), Long Beach, CA, USA, 20-24 March 2016.

15. Pascual, C.; Krein, P.T. Switched capacitor system for automatic series battery equalization. In Proceedings of the APEC 97-Applied Power Electronics Conference, Atlanta, GA, USA, 27 February 1997.

16. Kim, M.Y.; Kim, C.H.; Kim, J.H.; Moon, G.W. A chain structure of switched capacitor for improved cell balancing speed of lithium-ion batteries. IEEE Trans. Ind. Electron. 2014, 61, 3989-3999. [CrossRef]

17. Jeon, S.; Kim, M.; Bae, S. Analysis of a symmetric active cell balancer with a multi-winding transformer. J. Electr. Eng. Technol. 2017, 12, 1812-1820. [CrossRef]

18. Kim, J.W.; Ha, J.I. Cell balancing method in flyback converter without cell selection switch of multi-winding transformer. J. Electr. Eng. Technol. 2016, 11, 367-376. [CrossRef] 
19. Stuart, T.; Zhu, W. Fast equalization for large lithium ion batteries. IEEE Aerosp. Electron. Syst. Mag. 2009, 24, 27-31. [CrossRef]

20. Kim, J.; Ha, J. Cell Balancing Control of Single Switch Flyback Converter Using Generalized Filters. In Proceedings of the 29th Annual IEEE Applied Power Electronics Conference and Exposition-APEC 2014, Fort Worth, TX, USA, 16-20 March 2014.

21. Hoque, M.M.; Hannan, M.A.; Mohamed, A.; Ayob, A. Battery charge equalization controller in electric vehicle applications: A review. Renew. Sustain. Energy Rev. 2017, 75, 1363-1385. [CrossRef]

22. Ling, R.; Wang, L.; Huang, X.; Dan, Q.; Zhang, J. A review of equalization topologies for lithium-ion battery packs. In Proceedings of the 34th Chinese Control Conference, Hanzhou, China, 28-30 July 2015.

23. Caspar, M.; Eiler, T.; Hohmann, S. Comparison of active battery balancing systems. In Proceedings of the 2014 IEEE Vehicle Power and Propulsion Conference (VPPC), Coimbra, Portugal, 27-30 October 2014.

24. Shang, Y.; Xia, B.; Zhang, C.; Cui, N.; Yang, J.; Mi, C.C. An Automatic Equalizer Based on Forward-Flyback Converter for Series-Connected Battery Strings. IEEE Trans. Ind. Electron. 2017, 64, 5380-5391. [CrossRef]

25. Li, S.; Mi, C.C.; Zhang, M. A high-efficiency active battery-balancing circuit using multiwinding transformer. IEEE Trans. Ind. Appl. 2013, 49, 198-207. [CrossRef]

26. Cao, J.; Schofield, N.; Emadi, A. Battery balancing methods: A comprehensive review. In Proceedings of the 2008 IEEE Vehicle Power and Propulsion Conference, Harbin, China, 3-5 September 2008.

27. Hua, C.C.; Fang, Y.H. A switched capacitor charge equalizer with cancellation mechanism of alternating current. In Proceedings of the 2015 IEEE 2nd International Future Energy Electronics Conference (IFEEC), Taipei, Taiwan, 1-4 November 2015.

28. Lim, C.S.; Lee, K.J.; Ku, N.J.; Hyun, D.S.; Kim, R.Y. A modularized equalization method based on magnetizing energy for a series-connected lithium-ion battery string. IEEE Trans. Power Electron. 2014, 29, 1791-1799. [CrossRef]

29. Kanade, S.A.; Puri, V. Electrical properties of thick-film NTC thermistor composed of Ni0.8Co0.2Mn2O4ceramic: Effect of inorganic oxide binder. Mater. Res. Bull. 2008, 43, 819-824. [CrossRef]

30. Daowd, M.; Antoine, M.; Omar, N.; van den Bossche, P.; van Mierlo, J. Single switched capacitor battery balancing system enhancements. Energies 2013, 6, 2149-2179. [CrossRef]

31. Ji, X.; Cui, N.; Shang, Y.; Zhang, C.; Sun, B. Modularized charge equalizer using multiwinding transformers for Lithium-ion battery system. In Proceedings of the 2014 IEEE Conference and Expo Transportation Electrification Asia-Pacific (ITEC Asia-Pacific), Beijing, China, 31 August-3 September 2014; pp. 1-5. [CrossRef]

32. Chen, H.; Zhang, L.; Han, Y. System-theoretic analysis of a class of battery equalization systems: Mathematical modeling and performance evaluation. IEEE Trans. Veh. Technol. 2015, 64, 1445-1457. [CrossRef]

33. Zhang, Z.; Gui, H.; Gu, D.J.; Yang, Y.; Ren, X. A hierarchical active balancing architecture for lithium-ion batteries. IEEE Trans. Power Electron. 2017, 32, 2757-2768. [CrossRef]

34. Park, H.-S.; Kim, C.-H.; Park, K.-B.; Moon, G.-W.; Lee, J.-H. Design of a charge equalizer based on battery Modularization. IEEE Trans. Veh. Technol. 2009, 58, 3216-3223. [CrossRef]

35. Uno, M.; Kukita, A. Modular equalization architecture using inter-module and switchless intra-module equalizer for energy storage system. In Proceedings of the 17th European Conference on Power Electronics and Applications, Geneva, Switzerland, 8-10 September 2015.

36. Ling, R.; Dan, Q.; Wang, L.; Li, D. Energy bus-based equalization scheme with bi-directional isolated Cuk equalizer for series connected battery strings. In Proceedings of the 2015 IEEE Applied Power Electronics Conference and Exposition (APEC), Charlotte, NC, USA, 15-19 March 2015.

37. Park, S.H.; Kim, T.S.; Park, J.S.; Moon, G.W.; Yoon, M.J. A new battery equalizer based on buck-boost topology. In Proceedings of the 7th Internatonal Conference on Power Electronics, ICPE'07, Daegu, Korea, 22-26 October 2007; pp. 962-965.

38. Lee, Y.S.; Cheng, G.T. Quasi-resonant zero-current-switching bidirectional converter for battery equalization applications. IEEE Trans. Power Electron. 2006, 21, 1213-1224. [CrossRef]

(C) 2018 by the authors. Licensee MDPI, Basel, Switzerland. This article is an open access article distributed under the terms and conditions of the Creative Commons Attribution (CC BY) license (http:/ / creativecommons.org/licenses/by/4.0/). 